\title{
Environmental responses to Lateglacial climatic fluctuations recorded in the sediments of pre-Alpine Lake Mondsee (northeastern Alps)
}

1. Stefan Lauterbach ${ }^{1, *}$,

2. Achim Brauer ${ }^{1}$,

3. Nils Andersen ${ }^{2}$,

4. Dan L. Danielopol ${ }^{3, \dagger}$,

5. Peter Dulski ${ }^{1}$,

6. Matthias Hüls ${ }^{2}$,

7. Krystyna Milecka ${ }^{4}$,

8. Tadeusz Namiotko ${ }^{5}$,

9. Milena Obremska ${ }^{4}$,

10. Ulrich Von Grafenstein ${ }^{6}$,

11. Declakes Participants

Keywords: Lateglacial; climate; lake sediments; Austria; sediment microfacies; $\mu-X R F$ scanning; pollen; stable isotopes

\section{Abstract}

Investigation of the sedimentary record of pre-Alpine Lake Mondsee (Upper Austria) focused on the environmental reaction to rapid Lateglacial climatic changes. Results of this study reveal complex proxy responses that are variable in time and influenced by the long-term evolution of the lake and its catchment. A new field sampling approach facilitated continuous and precisely controlled parallel sampling at decadal to sub-annual resolution for $\mu$-XRF element scanning, carbon geochemistry, stable isotope measurements on ostracods, pollen analyses and large-scale thin sections for microfacies analysis. The Holocene chronology is established through microscopic varve counting and supported by accelerator mass spectrometry ${ }^{14} \mathrm{C}$ dating of terrestrial plant macrofossils, whereas the Lateglacial age model is based on $\delta^{18} \mathrm{O}$ wiggle matching with the Greenland NGRIP record, using the GICC05 chronology. Microfacies analysis enables the detection of subtle sedimentological changes, proving that depositional processes even in rather large lake systems are highly sensitive to climate forcing. Comparing periods of major warming at the onset of the Lateglacial and Holocene and of major cooling at the onset of the Younger Dryas reveals differences in proxy responses, reflecting threshold effects and ecosystem inertia. Temperature increase, vegetation recovery, decrease of detrital flux and intensification of biochemical calcite precipitation at the onset of the Holocene took place with only decadal leads and lags over a ca. 100 a period, whereas the spread of woodlands and the reduction of detrital flux lagged the warming at the onset of the Lateglacial Interstadial by ca. 500-750 a. Cooling at the onset of the Younger Dryas is reflected by the simultaneous reaction of $\delta^{18} \mathrm{O}$ and vegetation, but sedimentological changes (reduction of endogenic calcite content, increase in detrital flux) were delayed by about 150-300 a. Three short-term Lateglacial cold intervals, corresponding to Greenland isotope substages $\mathrm{GI}-1 \mathrm{~d}, \mathrm{GI}-1 \mathrm{c} 2$ and $\mathrm{Gl}-1 \mathrm{~b}$, also show complex proxy responses that vary in time. 


\section{Introduction}

Rapid climatic changes across the Last Glacial/Holocene transition are documented in the Greenland ice cores (e.g. Johnsen et al., 1992; Rasmussen et al., 2006) and various lacustrine (e.g. von Grafenstein et al., 1999a; Birks and Ammann, 2000; Brauer et al., 2000; Litt et al., 2001; Marshall et al., 2002; Magny et al., 2006; Yu, 2007; Brauer et al., 2008a) and marine (e.g. Haflidason et al., 1995; Hughen et al., 2000) palaeoclimate archives in the North Atlantic realm. Improved understanding of the regional environmental impact of these climatic changes is a prerequisite for assessing the effects of future climate variability on ecosystems and the dynamics of these processes. Within this context, continental archives are ideal to associate climatic changes directly with the environmental response in the human habitat. Previous studies on lacustrine records from the climate-sensitive region of the European Alps added a wealth of information on Lateglacial climate fluctuations (e.g. von Grafenstein et al., 1999a; Schwander et al., 2000) and their impact on terrestrial and aquatic ecosystems (e.g. Eicher and Siegenthaler, 1976; Eicher et al., 1981; Ammann and Lotter, 1989; Schmidt et al., 1998; Lotter, 1999; Lotter et al., 2000; Heiri and Millet, 2005; Finsinger et al., 2008) and depositional processes (e.g. Moscariello et al., 1998; Brauer and Casanova, 2001). While high-resolution studies have shown that particularly small lake systems record even low-amplitude climatic changes and related environmental responses (e.g. Lotter et al., 1992; Litt and Stebich, 1999; Ammann et al., 2000; Brauer et al., 2000), less is known about the climate sensitivity of lakes with a comparatively large catchment area. Hence, detailed investigation of the sedimentary record of pre-Alpine Lake Mondsee (Upper Austria) can aid our understanding of the impact of rapid Lateglacial climate fluctuations on the local ecosystem and the climate sensitivity of sedimentological processes in a rather large lake system. It furthermore provides new information on the regional climate development in the northeastern Alps and thus on the climatic differentiation in Europe during the Late- and Postglacial.

This study, associated with the European Science Foundation EuroCLIMATE project DecLakes (Decadal Holocene and Lateglacial variability of the oxygen isotopic composition in precipitation over Europe reconstructed from deep-lake sediments), presents detailed sediment microfacies data combined with high-resolution multi-proxy analyses obtained on a new Lateglacial to Holocene sediment core from Lake Mondsee, northeastern Alps, Austria. Particular care was taken on the parallel sampling for all analyses, enabling direct comparison of various proxy data and detailed microscopic inspection of each individual sample interval. The main purpose of this paper is the detailed investigation of the variable proxy responses to rapid Lateglacial climatic fluctuations. Forthcoming publications will address in detail the ostracod assemblage succession and the interpretation of the stable isotope record in order to 
shed light on the complex relationships between air temperature, $\delta^{18} \mathrm{O}$ in precipitation, $\delta^{18} \mathrm{O}$ in lake water, water temperature and resulting $\delta^{18} \mathrm{O}$ in ostracod valves.

\section{Study Site}

Pre-Alpine Lake Mondsee is situated at the northern margin of the European Alps ( $47^{\circ} 49^{\prime} \mathrm{N}, 13^{\circ}$ 24'E, $481 \mathrm{~m}$ above sea level (a.s.l.)) in the Salzkammergut lake district of Upper Austria, about $40 \mathrm{~km}$ east of Salzburg (Fig. 1). The oligo-mesotrophic hardwater lake (maximum water depth $\sim 68 \mathrm{~m}$, surface area $\sim 14.2 \mathrm{~km}^{2}$, volume $\sim 5.1 \mathrm{~km}^{2}$ ) can be subdivided into a shallow northern and a deeper southern basin (Jagsch and Megay, 1982). Three major tributaries (Fuschler Ache, Zeller Ache and Wangauer Ache) and several minor streams discharge into the lake, which drains via the small river Seeache into Lake Attersee.

The catchment area of Lake Mondsee has a size of $\sim 247 \mathrm{~km}^{2}$, of which about $50 \%$ is covered by forests (Beiwl, 2008). Two major geological units, separated by a thrust zone that follows the southern shoreline of Lake Mondsee, characterise the area (Fig. 1). The steep-sloped mountains of the Northern Calcareous Alps along the southern lakefront, which are composed of the Triassic Main Dolomite and Mesozoic limestones and reach elevations of up to $1782 \mathrm{~m}$ a.s.1., constitute about $25 \%$ of the catchment area. Cretaceous marls, shales and sandstones of the Rhenodanubic Flysch and local Quaternary deposits, which dominate the remaining $\sim 75 \%$ of the catchment, characterise the gently sloped hills in the eastern, western and northern part of the catchment, generally not exceeding elevations of $\sim 1000 \mathrm{~m}$ a.s.l. (van Husen, 1989). During the Pleistocene, the lake basin, originally formed by tectonic processes, has been repeatedly overridden and substantially altered by glacier activity, finally by the Traun Glacier during the Würmian glaciation (van Husen, 1979; Kohl, 1998). Eemian palaeolake deposits on the northern shore, which are covered by Würmian tills (Klaus, 1975; Drescher-Schneider and Papesch, 1998), indicate the complex evolution and larger-thanpresent extent of the lake basin during earlier times. Direct glacier influence on the catchment rapidly ceased after the Last Glacial Maximum as indicated by kame deposits of the Ischler Stand (Bühl Stadial) about $15 \mathrm{~km}$ southeast of Lake Mondsee (van Husen, 1977, 1997). The corresponding early phase of the Lateglacial ice decay (Reitner, 2007) in the lower eastern Alpine valleys dates to ca. 18 000-19 000 cal. a BP (van Husen, 1977, 2004; Schmidt et al., 1998; Klasen et al., 2007). After the ice retreat, the glacial basin was subsequently filled by meltwater, forming the present lake.

Today, the study area is characterised by an Alpine-influenced temperate climate with warm summers and frequent precipitation. The mean annual air temperature for the weather station Mondsee is $+8.7^{\circ} \mathrm{C}$ with January and July means of $-0.5^{\circ} \mathrm{C}$ and $+17.8^{\circ} \mathrm{C}$, respectively. The average annual precipitation amounts to about $1550 \mathrm{~mm}$, with highest rainfall during summer 
(climate data for the period 1971-2000, Central Institute for Meteorology and Geodynamics (ZAMG), Vienna, Austria).

Past work on Lake Mondsee sediments mainly focused on recent and late Holocene limnological and sedimentological aspects (e.g. Löffler, 1983; Behbehani et al., 1985; Danielopol et al., 1985; Irlweck and Danielopol, 1985; Horsthemke, 1986; Klee and Schmidt, 1987; Herrmann, 1990), but also included a low-resolution study on the Lateglacial to Holocene vegetation development (Schultze and Niederreiter, 1990).

\section{Fieldwork and Methods}

\section{Fieldwork}

Two parallel sediment cores (1389 and $1172 \mathrm{~cm}$ long), each consisting of 2-m-long segments (Fig. 2, were recovered from the coring site $\left(47^{\circ} 48^{\prime} 41^{\prime} \mathrm{N}, 13^{\circ} 24^{\prime} 09^{\prime} \mathrm{E}, 62 \mathrm{~m}\right.$ water depth) in the southern lake basin (Fig. 1) in June 2005 by using a $90 \mathrm{~mm}$ diameter UWITEC piston corer. Additionally, the undisturbed sediment-water interface was obtained in three short gravity cores recovered from the same site. A field lab was installed to facilitate on-site core opening, photographing and preliminary lithostratigraphical description. The overlapping segments of both cores were visually correlated by using more than 90 macroscopic lithological marker layers, resulting in a continuous composite profile of about $1500 \mathrm{~cm}$ length (Fig. 2). The subsequent continuous and precisely parallel sampling of the core segments for all proxy analyses was also carried out in the field lab.

\section{Sediment Microfacies Analysis and Varve Counting}

Detailed sediment microfacies investigation, also confirming the preliminary macroscopic core correlation, was carried out on large-scale petrographic thin sections prepared from a continuous series of overlapping sediment blocks $(100 \times 20 \times 10 \mathrm{~mm})$ according to the method described by Brauer et al. (1999b). Thin sections were examined under a Zeiss Axiophot polarisation microscope at 25-400× magnification. Additionally, microscopic counting of biochemical calcite varves, including thickness measurements, was carried out within the uppermost $1129.0 \mathrm{~cm}$ of the profile. For a detailed account on the establishment of the varve chronology for the Holocene part of the profile and the supplementary accelerator mass spectrometry (AMS) radiocarbon dating of terrestrial plant macrofossils, we refer to the online Supporting information (Fig. S1 and Table S1).

\section{Geochemical Analyses}


Bulk sediment samples for quantitative carbon geochemistry $(0.5$-cm-thick slices) from the interval 1112.0-1279.0 cm were analysed continuously across climatic transitions, defined according to microfacies and stable isotope data, and with sample increments of $1-2 \mathrm{~cm}$ in the remaining sections. Total inorganic carbon (TIC) was measured coulometrically on freezedried and homogenised samples ( $\sim 50 \mathrm{mg}$ ) using a Ströhlein Coulomat 702 elemental analyser. Total carbon (TC) was determined by combustion of sample material (100-200 mg) at $1350{ }^{\circ} \mathrm{C}$ in a LECO CNS-2000 analyser. Total organic carbon (TOC) was calculated as the difference between TC and TIC with an estimated analytical error of $\sim 0.3 \%$. All results are expressed as per cent dry weight.

Semi-quantitative major element scanning was carried out at $200 \mu \mathrm{m}$ resolution on impregnated sediment slabs from thin-section preparation between 1064.0 and $1302.0 \mathrm{~cm}$, using a vacuum-operating Eagle III XL micro X-ray fluorescence ( $\mu$-XRF) spectrometer with a low-power $\mathrm{Rh} X$-ray tube at $40 \mathrm{kV}$ and $300 \mu \mathrm{A}$ ( $250 \mu \mathrm{m}$ spot size, $60 \mathrm{~s}$ counting time, single scan line). The fluorescent radiation emitted from the sample was recorded by an energydispersive $\mathrm{Si}(\mathrm{Li})$ detector and transformed into element information for each measuring point. Element intensities for $\mathrm{Mg}, \mathrm{Al}$ and $\mathrm{Ca}$ are expressed as counts s $\mathrm{s}^{-1}$ (cps), representing relative changes in element composition. Combined interpretation of high-resolution $\mu$-XRF and microfacies data is enabled as the scanned sediment surfaces are identical to those prepared for thin sections (Brauer et al., 2009).

\section{Stable isotopes}

For high-resolution stable isotope measurements on ostracods, 0.5 -cm-thick sediment slices were taken continuously between 1060.0 and $1273.5 \mathrm{~cm}$. Samples were disaggregated in $10 \%$ $\mathrm{H}_{2} \mathrm{O}_{2}$, wet sieved through a $125-\mu \mathrm{m}$ mesh and rinsed in ethanol before drying. Subsequently, valves of juvenile (5th-8th stage) Candona neglecta and Fabaeformiscandona harmsworthi (Namiotko et al., 2009) were separated and mechanically cleaned at the Institute for Limnology in Mondsee. Subsets of up to 20 valves $(15-110 \mu \mathrm{g})$ of Candona neglecta (above $1212.0 \mathrm{~cm}$ ) and Fabaeformiscandona harmsworthi (below $1212.0 \mathrm{~cm}$ ) were analysed for $\delta^{13} \mathrm{C}$ and $\delta^{18} \mathrm{O}$ at the Leibniz Laboratory in Kiel on a CARBO Kiel I / Finnigan MAT $251 \mathrm{CO}_{2}$ preparation and mass spectrometer system. Isotopic compositions are reported in the conventional $\delta$-notation relative to the Vienna PeeDee Belemnite (VPDB) standard. The analytical precision is $<0.04 \%$ and $<0.07 \%$ for $\delta^{13} \mathrm{C}$ and $\delta^{18} \mathrm{O}$, respectively. The change of the measured species at $1212.0 \mathrm{~cm}$ has no influence on the oxygen isotope record as $\delta^{18} \mathrm{O}$ derived from different Candonidae is comparable because of the identical vital offset of about $+2.2 \%$ o compared to equilibrium calcite (von Grafenstein et al., 1999b).

\section{Pollen}


For pollen analyses, carried out at the Adam Mickiewicz University in Poznań, 0.5-cm-thick sediment slices from the interval $1112.0-1279.0 \mathrm{~cm}$ were analysed continuously across climatic transitions and with increments of up to $2.5 \mathrm{~cm}$ in the remaining sections. Two Lycopodium tablets were added to each sample for the calculation of pollen concentrations (Stockmarr, 1971). Sample preparation followed the standard method described by Berglund and Ralska-Jasiewiczowa (1986), including treatment with cool $\mathrm{HF}$ and $\mathrm{HCl}$, acetolysis, embedding in pure glycerine and staining with safranin. A minimum of 500 terrestrial pollen grains were counted and determined under a light microscope (400× magnification) for samples above $1200.0 \mathrm{~cm}$, while less than 100 pollen grains per sample were counted below this depth due to the low pollen concentrations. The TILIA/TILIA GRAPH

\section{Results}

\section{Sediment Microfacies and Geochemistry}

The Lake Mondsee sediment record is subdivided into five major lithostratigraphical units (Lithozones I-V), distinguished by (i) the amount of minerogenic detrital material, (ii) the quantity of endogenic calcite and (iii) the presence and structure of lamination (Figs $\underline{2}$ and $\underline{3}$ ). $\mathrm{Ca} / \mathrm{Mg}$ ratios (Fig. 4) allow differentiation between intervals with predominantly detrital input (low ratios, high content of Mg-rich dolomitic material) and such with mainly autochthonous sedimentation (high ratios, dominant biochemical calcite precipitation). Polarisation and scanning electron microscopy corroborate a close correspondence between high- $\mathrm{Ca} / \mathrm{Mg}$ ratio intervals and the abundant occurrence of idiomorphic, biochemically precipitated calcite. We thus consider fluctuations in the broadly similar $\mu$-XRF Ca and TIC records to mainly reflect changes in endogenic calcite contents. In contrast, the $\mu$-XRF Mg record is regarded as a proxy for the input of detrital dolomite from the Northern Calcareous Alps. It largely coincides with the $\mu$-XRF Al record, which is considered to reflect the second component of detrital input, the supply of siliciclastic detrital material from the Flysch Zone.

Lithozone I (1493.0-1274.0 cm) is composed of yellowish/brownish-grey, distinctly laminated sediments. Regular light-dark couplets (average thickness $\sim 1.0-1.5 \mathrm{~mm}$; Fig. $\underline{3} \mathrm{~A}$ ) contain a darker (greyish) basal silt layer, which is composed of detrital carbonates and subordinated siliciclastics and reveals a sharp lower boundary. Towards the top, the silt layer grades into a lighter (yellowish) clay layer with decreasing carbonate content. The gradation of these silt-clay laminae reflects the temporally differentiated deposition of silt and clay by over- and interflows after spring meltwater discharge (Sturm and Matter, 1978). Sporadic dropstones in the silt layer (Fig. $\underline{3} \mathrm{~A}$ ) indicate drift-ice transport and thus seasonal ice cover. About 160, silt- to fine sand-sized turbidites are intercalated within the regular silt-clay laminae. Although having an identical mineralogical composition, the distinctly graded 
turbidites are usually thicker (up to several centimetres) and frequently show erosional basal contacts (Fig. $\underline{3}$ A), thus suggesting deposition by underflows (Sturm and Matter, 1978). The predominantly dolomitic and siliciclastic composition of Lithozone I sediments is reflected by elevated $\mathrm{Mg}$ and $\mathrm{Al}$ counts, respectively (Fig. 4). As confirmed by microscopic analyses, the low Ca counts and TIC contents $(<5.0 \%)$ exclusively reflect detrital carbonates.

The deposition of silt-clay laminae with intercalated turbidites continues throughout Lithozone II (1274.0-1195.0 cm). However, as observed in thin sections, the transitional boundary between Lithozones I and II can be defined by the first appearance of biochemically precipitated calcite and the decrease in average laminae thickness from $\sim 1.0-1.5 \mathrm{~mm}$ to less than $1.0 \mathrm{~mm}$. Sediment colour gradually changes from yellowish/brownish grey to light grey towards the top of Lithozone II. This is the result of the increasing amount of endogenic calcite, allowing the definition of two lithostratigraphical subzones. Microscopic inspection reveals that idiomorphic, microcrystalline calcite $(<5 \mu \mathrm{m})$ is still rare below $1224.0 \mathrm{~cm}$ (Lithozone IIa), but becomes more abundant above (Lithozone IIb). This is reflected by a rise in Ca counts and TIC contents (from about 6.0\% to 8.5\%) throughout Lithozone IIb (Fig. 4 ) and most probably related to intensified biological productivity (Brauer and Casanova, 2001). The parallel reduction of detrital flux, indicated by decreasing $\mathrm{Al}$ and $\mathrm{Mg}$ counts, results in a more faint lamination. A slight increase in TOC from about $0.3 \%$ to $0.5-0.8 \%$ around $1201.0 \mathrm{~cm}$ marks the onset of the gradual transition between Lithozones II and III.

Light-grey, homogeneous lake marl, which predominantly consists of endogenic calcite, dominates throughout Lithozone III $(1195.0-1169.0 \mathrm{~cm})$. Only a few silt-sized detrital carbonates and siliciclastics are finely dispersed within the clay-sized matrix (Fig. $\underline{3}$ B). The absence of a lamination is owed to the lack of episodic detrital input, which is indicated by low $\mathrm{Al}$ and $\mathrm{Mg}$ counts (Fig. $\underline{4})$. High amounts of endogenic calcite are reflected by maximum Ca counts and TIC contents of 8.5-10.0\% ( 70-80\% $\left.\mathrm{CaCO}_{3}\right)$, only interrupted by distinct reductions at $1195.5-1190.5 \mathrm{~cm}$ and $1181.0-1175.5 \mathrm{~cm}$ (Fig. 4). Within these two intervals, up to 4-mm-thick clay layers occur, corresponding to elevated $\mathrm{Al}$ counts (Figs $\underline{3 \mathrm{~B}}$ and $\underline{4}$ ). The gradual transition towards Lithozone IV in the uppermost $5 \mathrm{~cm}$ of Lithozone III is characterised by the reappearance of regular episodic clay layers, resulting in a faint carbonate-clay lamination.

Lithozone IV $(1169.0-1129.0 \mathrm{~cm})$ is characterised by laminated light-grey lake marl. Faint laminae couplets of about $1 \mathrm{~mm}$ thickness comprise, as observed in Lithozone II, a silty basal sub-layer with detrital carbonates and an overlying clayey sub-layer (Fig. $\underline{3 C}$ ). Numerous yellowish-brownish, 0.3-8.0-mm-thick detrital layers with frequent erosional basal contacts are intercalated within the regular silt-clay laminae. These turbidites contain silt-sized detrital carbonates and siliciclastics and in most cases also fine-grained organic material. Higher 
detrital flux in Lithozone IV is reflected by an overall increase in $\mathrm{Al}$ and $\mathrm{Mg}$ counts, with distinct spikes in the $\mathrm{Mg}$ record reflecting the frequent occurrence of turbidites (Figs $\underline{3 \mathrm{C}}$ and 4). In contrast, endogenic calcite contents are reduced as indicated by decreasing Ca counts and TIC contents (Fig. 4), reaching lowest values between about 1168.0 and $1157.0 \mathrm{~cm}$.

The sediments of Lithozone V (above $1129.0 \mathrm{~cm}$ ) are composed of millimetre- to submillimetre-scale laminated lake marl that contains abundant ostracod valves and plant macro remains (leaves, needles, seeds and wood fragments). Sediment colour gradually changes from light to yellowish/brownish-grey upcore, which is mainly related to the increasing abundance of organic matter. Intensified biochemical calcite precipitation is reflected by increased $\mathrm{Ca}$ counts and TIC contents of up to $10.0 \%\left(\sim 70-85 \% \mathrm{CaCO}_{3}\right)$ at the base of Lithozone $\mathrm{V}$, whereas reduced $\mathrm{Al}$ and $\mathrm{Mg}$ counts prove the low minerogenic input (Fig. $\underline{4}$ ). Light-dark laminae couplets (supporting Fig. S1) exhibit a light basal layer of microcrystalline $(<5 \mu \mathrm{m})$ endogenic calcite. Occasionally, a sub-lamination with larger calcite crystals at the base and smaller ones on top indicates two pulses of calcite precipitation (Kelts and Hsü, 1978; Lotter, 1989; Brauer et al., 2008b). The calcite layer is overlain by a dark layer that contains clay minerals, amorphous organic material, partly dissolved diatom frustules and only a few endogenic calcite crystals. In summary, these light-dark couplets, which are best preserved in the upper $\sim 610 \mathrm{~cm}$ of the profile, represent typical biochemical calcite varves (e.g. Lotter, 1989; Lotter et al., 1997; Brauer and Casanova, 2001). Average varve thickness gradually increases from $\sim 0.5 \mathrm{~mm}$ at the base of Lithozone $\mathrm{V}$ to $\sim 2.0 \mathrm{~mm}$ in the uppermost $150 \mathrm{~cm}$ (supporting Fig. S1), but shows only minor short-term fluctuations. Two types of detrital layers are intercalated within the regular varve succession: (i) macroscopic brownish detrital layers of up to several millimetres thickness, which are composed of detrital carbonates, subordinated siliciclastics and coarse organic debris; and (ii) microscopic detrital layers, which usually do not exceed $100 \mu \mathrm{m}$ in thickness and contain higher amounts of siliciclastics but only a few organic material (Swierczynski et al., 2009).

\section{Stable Isotope Ratios}

The stable oxygen isotope record derived from the valves of juvenile Candonidae (Fig. 5) reveals the characteristic pattern of Lateglacial climatic changes, which is also seen in other Alpine oxygen isotope records (e.g. Eicher, 1987; Lotter et al., 1992; von Grafenstein et al., 1999a; Schwalb, 2003) and the Greenland ice cores (e.g. Johnsen et al., 1992; NGRIP members, 2004). The close correspondence to the $\delta^{18} \mathrm{O}$ records from adjacent Lake Ammersee and Greenland (Fig. 7), which are mainly controlled by temperature variability (Johnsen et al., 1992; Stuiver et al., 1995; von Grafenstein et al., 1996, 1999a), but also the agreement with regional temperature reconstructions based on biotic proxy data (Heiri and Millet, 2005), implies that the Lake Mondsee $\delta^{18} \mathrm{O}$ record also reflects mainly a temperature signal. 
However, it might be additionally influenced by other factors, e.g. hydrological or atmospheric circulation changes. Oxygen isotope ratios rapidly increase by $\sim 2.0 \%$ at the base of Lithozone II (Pleniglacial/Lateglacial transition), while $\delta^{13} \mathrm{C}$ values gradually decrease from about $-5.5 \%$ o to $-9.0 \%$ in Lithozone II. Throughout Lithozones II and III, $\delta^{18} \mathrm{O}$ ratios fluctuate around $-6.0 \%$, superimposed by three minor negative excursions of about $0.8-1.5 \%$ o at $1215.0-1201.5 \mathrm{~cm}, 1195.0-1191.5 \mathrm{~cm}$ and $1182.5-1175.0 \mathrm{~cm}$, which are termed Mo-LG1, Mo-LG2 and Mo-LG3, respectively. $\delta^{13} \mathrm{C}$ values decrease from about $-9.0 \%$ to $-10.0 \%$ within Lithozone III. Across the transition between Lithozone III and IV $(1173.0-1168.0 \mathrm{~cm})$, $\delta^{18} \mathrm{O}$ decreases by about $2.5 \%$, reflecting the onset of the Younger Dryas. Throughout Lithozone IV, oxygen isotope ratios gradually rise by about $1.0 \%$, but remain below $-7.5 \%$. Shortly before the base of Lithozone $\mathrm{V}$ at about $1131.5 \mathrm{~cm}, \delta^{18} \mathrm{O}$ ratios rapidly rise within $1.5 \mathrm{~cm}$ from about -8.0 to $-6.0 \%$. $\delta^{13} \mathrm{C}$ gradually increases from about $-10.0 \%$ to $-9.0 \%$ during the first half of Lithozone IV $(1169.0-1159.0 \mathrm{~cm})$ and then again decreases above $\sim 1141.0 \mathrm{~cm}$ to about $-9.5 \%$ in Lithozone $\mathrm{V}$.

\section{Pollen}

The pollen diagram exhibits a succession of seven local pollen assemblage zones (LPAZ, Fig. 6), in agreement with the regional Lateglacial vegetation development (Draxler, 1977; Schmidt, 1981; Draxler and van Husen, 1987) and allowing the definition of biostratigraphic boundaries. Open plant communities (shrubs and herbs) dominate the interval below $1250.0 \mathrm{~cm}$ (Lithozone I and basal Lithozone II), but low pollen concentrations prevent detailed vegetation reconstruction. The lowermost pollen zone LPAZ $1(1250.0-1216.0 \mathrm{~cm})$ is characterised by dwarf shrub communities of Juniperus, Salix and Betula nana interspersed with herbs. LPAZ $2(1216.0-1210.0 \mathrm{~cm})$ reflects the rapid expansion of Pinus (up to 80\%) and the decline of Juniperus. LPAZ 3 (1210.0-1201.0 cm) and LPAZ 4 (1201.0-1191.0 cm) reveal the further spread of Pinus, but heliophytic plants (Poaceae, Chenopodiaceae, Artemisia, Juniperus) still frequently occur. Declining values for Juniperus (below 2\%) and NAP characterise LPAZ 5 (1191.0-1169.5 cm), which corresponds to the Allerød pollen zone. The presence of Dryopteris filix-mas, nowadays restricted to temperate climates (Zarzycki et al., 2002), indicates warmer climate conditions. The increase of Artemisia (up to $2 \%$ ) and NAP (2-6\%) marks the base of LPAZ $6(1169.5-1130.0 \mathrm{~cm})$, which corresponds to the Younger Dryas pollen zone and shows a clear bipartition with NAP prevailing in the lower part (below $1157.0 \mathrm{~cm}$ ) and Juniperus dominating (up to 7\%) above this depth. Opening of forest cover within this zone is indicated by fluctuations in the Pinus curve and decreased tree pollen concentrations. The onset of the Holocene at the base of LPAZ 7 (above $1130.0 \mathrm{~cm}$ ) is reflected by the decline of Lateglacial shrubs and herbs.

\section{Chronology}


The age-depth model for the Holocene part of the Lake Mondsee sediment record, which is largely equivalent to Lithozone $\mathrm{V}$, was established through microscopic varve counting and is supported by AMS radiocarbon dating of terrestrial macrofossils. The base of Lithozone $\mathrm{V}$ at $1129.0 \mathrm{~cm}$ is dated to ca. 11510 varve a BP (for more details see the online supporting Appendix S1). For the Lateglacial interval, AMS ${ }^{14} \mathrm{C}$ dating and varve counting were not possible due to the lack of datable terrestrial macro remains and the failure to prove the annual origin of the fine lamination in Lithozones I, II and IV. Layer counting within the Lateglacial Interstadial interval (Lithozones II-IV) revealed a total of $\sim 800$ laminae couplets, which is significantly less than reported from proven annually laminated lake sediment records (e.g. Brauer et al., 1999b) and the Greenland ice cores (Rasmussen et al., 2006). However, a hiatus as a possible explanation for this difference is excluded because of the close agreement of the $\delta^{18} \mathrm{O}$ record even for small-scale fluctuations with other Alpine isotope records (e.g. Eicher, 1987; Lotter et al., 1992; von Grafenstein et al., 1999a).

Therefore, the Lateglacial age model was compiled by wiggle matching the Lake Mondsee ostracod-derived $\delta^{18} \mathrm{O}$ record to the NGRIP record from Greenland, using the recent GICC05 chronology (Rasmussen et al., 2006), which was corrected by an offset of -65 a (Muscheler $e t$ $a l ., 2008)$ and transferred to the BP time scale. Six distinct isotopic marker points were identified in both the Lake Mondsee and the NGRIP $\delta^{18} \mathrm{O}$ record (Fig. $7 \mathrm{~A}$ ) with the corresponding ages in the NGRIP record being used as tie points for the Lake Mondsee Lateglacial chronology (Table 1). Sample ages were linearly interpolated between the varvedated base of Lithozone $\mathrm{V}$ and these tie points with thick turbidites being excluded as instantaneous (time-neutral) depositional events. Owing to the lack of isotopic markers in Lithozone I, no age model was established for the interval prior to $14625 \mathrm{cal}$. a BP.

The Younger Dryas/Holocene boundary in the Lake Mondsee sediment record is defined by both biostratigraphy, namely the top of LPAZ 6 at $1130.0 \mathrm{~cm}$, and the pronounced $\delta^{18} \mathrm{O}$ rise between 1131.5 and $1130.0 \mathrm{~cm}$. The assigned age of $11580-11540 \mathrm{cal}$. a BP is similar to the Lake Meerfelder Maar varve chronology (11 590 varve a BP; Brauer et al., 1999a), the German pine chronology (11 570 cal. a BP; Friedrich et al., 1999) and the corrected NGRIP GICC05 chronology (11 605-11 545 cal. a BP; Rasmussen et al., 2006; Muscheler et al., 2008).

Temporal resolution for pollen, stable isotope and carbon geochemistry data is in the order of ca. 5-60 a throughout the investigated interval, with highest resolutions across climatic transitions. $\mu$-XRF measurements are continuously sub-annually resolved.

\section{Discussion}




\section{Proxy Response to Warming at the Onset of the Lateglacial and Holocene}

The Pleniglacial period was characterised by predominantly clastic-detrital sedimentation, which reflects extensive catchment erosion favoured by the sparse, shrub- and herbdominated vegetation. Subsequent rapid warming at the onset of the Lateglacial Interstadial is clearly reflected by the marked $\delta^{18} \mathrm{O}$ rise at the base of Lithozone IIa (Figs $\underline{4}$ and $\underline{8}$ ), which according to the correlation with the NGRIP chronology occurred between 14625 and 14 565 cal. a BP. Detrital input slightly decreased but prevailed for another ca. 500 a until 14 100 cal. a BP (base of Lithozone IIb), indicating a rather slow initial catchment stabilisation. During the following ca. 250 a (14 100-13 850 cal. a BP), the decrease of allochthonous matter flux accelerated (Fig. 4), likely as a result of the establishment of dense Pinus forests and related catchment stabilisation. Gradual soil development during the first ca. 750 a of the Lateglacial is also indicated by decreasing $\delta^{13} \mathrm{C}$ values, reflecting the increased supply of ${ }^{13} \mathrm{C}$ depleted $\mathrm{CO}_{2}$ from soil respiration (Hammarlund et al., 1997). The timing of the Pinus expansion in the Lake Mondsee record around $14000 \mathrm{cal}$. a BP is consistent with results from other Alpine sites (Draxler, 1977; Ammann and Lotter, 1989; Lotter, 1999; Schmidt et al., 2002). As temperatures at the northern Alpine margin were sufficient for forest establishment already several hundred years earlier (Ammann, 1989), which is also indicated by the Lake Mondsee $\delta^{18} \mathrm{O}$ record, the delay in the spread of Pinus forests rather reflects not a climatic signal but migrational lags (Gaillard, 1985; Ammann et al., 1994) and slow soil development. Delayed forest establishment might have been amplified by discontinuous permafrost (Hoek, 2001), which was preserved in the catchment area during the early Lateglacial Interstadial (van Husen, 1997). Permafrost persistence could also explain the high detrital matter flux until ca. 14100 cal. a BP, as reduced seepage would have caused enhanced surface runoff and erosion (Stebich et al., 2009). Although microscopic evidence for the first occurrence of endogenic calcite at the base of Lithozone IIa clearly indicates a synchronous productivity increase in response to the warming at about $14600 \mathrm{cal}$. a BP, the major rise in Ca counts and TIC contents occurred only after $14100 \mathrm{cal}$. a BP. This might be related to dilution effects through the dominant detrital matter flux (Loizeau et al., 2001) during the first ca. 500 a of the Lateglacial Interstadial.

In contrast to the gradual environmental changes at the onset of the Lateglacial Interstadial, environmental response to the Holocene warming was more rapid and reveals less pronounced leads and lags between proxy data (Fig. 9). Both the reduction of surface runoff and the increase in calcite precipitation started synchronously with the rapid $2 \% 0 \delta^{18} \mathrm{O}$ rise, but continued for further ca. $60 \mathrm{a}$ after $\delta^{18} \mathrm{O}$ had already reached Holocene levels. Also the decline of shrub vegetation and the recovery of Pinus forests occurred parallel to the pronounced $\delta^{18} \mathrm{O}$ rise between ca. 11580 and $11540 \mathrm{cal}$. a BP. In particular, the biostratigraphically defined 
end of the Younger Dryas (LPAZ 6) coincides with the end of the $\delta^{18} \mathrm{O}$ rise. Immediate forest recovery in response to the temperature rise was possible because Pinus forests had survived locally during the Younger Dryas, proving the importance of ecological preconditions for the reflection of climatic changes in the pollen record (cf. Jones et al., 2002).

\section{Proxy Response to Cooling at the Onset of the Younger Dryas}

Climatic deterioration at the beginning of the Younger Dryas is well reflected by a 2.5\% drop in $\delta^{18} \mathrm{O}$ between ca. 12760 and 12590 cal. a BP. The slight Pinus decrease, which started already parallel to the $\delta^{18} \mathrm{O}$ drop, was followed by the increase of NAP (used for the biostratigraphic definition of the Younger Dryas onset at the base of LPAZ 6) within the second half of the oxygen isotope decrease at about $12640 \mathrm{cal}$. a BP. This indicates a short response time of local vegetation to climatic forcing. Simultaneous changes in vegetation and oxygen isotopes at the onset of Younger Dryas have also been described from Switzerland (Ammann et al., 2000) and Poland (Goslar et al., 1993). In the Lake Mondsee record, the expansion of shrub, grassland and herb communities at the base of LPAZ 6 was accompanied by a reduction in tree pollen concentrations, indicating opening of forest cover and reduced flowering in response to cooler climate conditions (Rundgren and Ingólfsson, 1999).

However, vegetation feedback was not as pronounced as at sites closer to ecotone boundaries, i.e. at higher altitudes (Ammann et al., 1993; Birks and Ammann, 2000; Wick, 2000) or closer to the remaining Scandinavian Ice Sheet (Goslar et al., 1993; Litt and Stebich, 1999; Merkt and Müller, 1999).

In contrast to the vegetation response, changes in the sedimentation regime around the onset of the Younger Dryas were rather complex. Microfacies analysis reveals a first minor increase in detrital matter flux (reappearance of faint silt-clay laminae) parallel to the onset of the $\delta^{18} \mathrm{O}$ decrease. This indicates that, similar to the end of the Younger Dryas, a subtle sedimentological change occurred synchronously with the climatic shift. However, more pronounced changes in the sedimentation regime as the reduction of calcite precipitation and the increase of allochthonous flux only occurred at the end of the temperature decrease around 12620 cal. a BP and continued for ca. 60 a after $\delta^{18} \mathrm{O}$ had already reached the low Younger Dryas level (Fig. 9). The delay in the reduction of calcite precipitation is difficult to explain because the presence of endogenic calcite in the sediments is influenced by a variety of factors, e.g. temperature, lake productivity or water chemistry. For example, a gradual increase in aridity or the establishment of permafrost might have reduced the availability of carbonate ions through groundwater flux and thus caused a delayed reduction in calcite precipitation. It could also reflect temperature threshold effects as endogenic calcite formation can persist even under low temperatures (Ohlendorf and Sturm, 2001). Moreover, also seasonality might have played a role as endogenic calcite formation is a proxy for 
spring/summer conditions and there is evidence from model studies (Isarin et al., 1998) and proxy data (Lücke and Brauer, 2004) that Younger Dryas winter cooling was more severe than the drop in summer temperatures. The delay in the first occurrence of distinct turbidites, which were deposited only ca. 130 a after the general increase of detrital flux, could be related to the gradual build-up of discontinuous permafrost in the catchment (cf. Stebich et al., 2009), but might also reflect the persistence of perennial snow fields or the build-up of small local glaciers in the Northern Calcareous Alps.

\section{Proxy Response to Short-Term Lateglacial Coolings}

The relatively warm conditions during the Lateglacial Interstadial are punctuated by three short negative $\delta^{18} \mathrm{O}$ excursions of $0.8-1.5 \%$, labelled as Mo-LG1, Mo-LG2 and Mo-LG3, which are interpreted as cold intervals (Fig. $\underline{8}$ ).

Mo-LG1 is characterised by a $\sim 1.5 \%$ drop in $\delta^{18} \mathrm{O}$, which lasted about 140 a (ca. $13985-13$ 845 cal. a BP) and corresponds to Greenland isotope substage GI-1d (Björck et al., 1998), the Aegelsee oscillation in Switzerland (Lotter et al., 1992) and a period of higher detrital flux (MK-4) in Lake Meerfelder Maar (Brauer et al., 2000). Rapid fluctuations superimposed on the general decrease in $\delta^{18} \mathrm{O}$ may result from the high temporal resolution (ca. 4 a per sample) during this interval as a consequence of the high sedimentation rate in Lithozone IIb. As MoLG1 occurred still within the 750 a period of elevated detrital matter flux during the early Lateglacial Interstadial, the $\delta^{18} \mathrm{O}$ decrease is not clearly reflected by sedimentological changes (Fig. ). Also vegetation development reveals an ambiguous response to the Mo-LG1 cooling as the replacement of Juniperus by Pinus forests rather indicates successive forest stabilisation than climatic deterioration. Thus climatic and vegetational development during this period appear to be decoupled, most probably owing to the superimposed migration processes (Ammann et al., 1994).

Cold interval Mo-LG2, which is characterised by a $\sim 1.0 \%$ drop in $\delta^{18} \mathrm{O}$, lasted ca. 155 a (ca. 13 625-13 470 cal. a BP). It correlates to a short period of lower $\delta^{18} \mathrm{O}$ values in the Lake Ammersee record (von Grafenstein et al., 1999a), to the ca. 180 a long isotope substage GI1c2 in the Greenland ice core records (Björck et al., 1998; Rasmussen et al., 2006) and probably to the Older Dryas pollen zone in the Eifel Maar lakes (Brauer et al., 2000). In contrast to Mo-LG1, the $\delta^{18} \mathrm{O}$ decrease coincides with a marked negative oscillation in Ca counts and TIC contents, reflecting the response of calcite precipitation to decreasing temperatures (Brunskill, 1969; Kelts and Hsü, 1978). Two distinct negative spikes in the Ca record and corresponding positive $\mathrm{Al}$ peaks are due to the presence of discrete clay layers (Figs $\underline{3}$ and $\underline{8}$ ), reflecting siliciclastic detrital matter deposition by extreme surface runoff events. The direct coupling between climate change and sedimentological response during 
cold interval Mo-LG2 provides evidence that under certain conditions even sedimentation in a large lake system is sensitive to minor climate changes. In contrast to the clear sedimentological shift, the pollen record reveals only a subdued response during Mo-LG2, suggesting that local forest cover at this time was sufficiently stable to compensate for the low-amplitude cooling. Although subtle changes in different Pinus species (Schmidt et al., 2002) cannot be excluded, the temperature decrease was, even if higher herb pollen and lower Pinus and Betula concentrations indicate a slight reduction in forest cover, not sufficient to exceed a critical threshold necessary for a major shift in forest composition. This probably reflects a certain insensitivity of vegetation at sites far from ecotone boundaries to small-scale climatic changes (Wohlfarth et al., 1994; Walker, 1995).

The $\sim 0.8 \%$ decrease in $\delta^{18} \mathrm{O}$ during Mo-LG3 lasted for ca. 290 a (ca. $13125-12835$ cal. a BP) and corresponds to Greenland isotope substage GI-1b (Björck et al., 1998) and the Gerzensee oscillation in Switzerland (Eicher and Siegenthaler, 1976; Lotter et al., 1992). The peak amplitude of the gradual $\delta^{18} \mathrm{O}$ decrease appears to be smaller than for the preceding two cold intervals, which is different than in Lake Ammersee (von Grafenstein et al., 1999a) and the Greenland ice cores (Rasmussen et al., 2006) and might be related to variations in local hydrology. The temperature decrease during Mo-LG3 was directly paralleled by a reduction in calcite precipitation after about 13125 cal. a BP, reflected by drops in TIC contents and Ca counts (Fig. ㅈ). Moreover, rising temperatures at the end of Mo-LG3 (ca. 12 910-12 835 cal. a BP) were paralleled by immediately increasing endogenic calcite contents. It is also striking that even the gradual $\delta^{18} \mathrm{O}$ decrease by about $0.5 \%$ during the ca. 135 a prior to Mo-LG3 is reflected by fluctuations in endogenic calcite contents. Although two discrete clay layers, reflected by discrete $\mathrm{Al}$ peaks, indicate sporadic surface runoff events, the interval between ca. 13615 and 12620 cal. a BP is characterised by rather low detrital contents and thus low erosion rates. This might be related to (i) increased aridity and thus decreased snow meltwalter discharge/surface runoff, (ii) increased infiltration of precipitation due to the disappearance of permafrost or (iii) further soil stabilisation through the spread of dense and stable late Allerød forest communities dominated by Pinus. Their ability to compensate lowamplitude cooling (Lotter et al., 1992; Wick, 2000) would explain the lack of a clear vegetational response to the Mo-LG3 cooling. The subdued reaction is restricted to slight reductions in the concentrations of tree pollen and Dryopteris filix-mas spores, indicating reduced flowering due to climatic cooling during this interval.

\section{Conclusions}


The combination of continuous microfacies data and sub-decadally to sub-annually resolved multi-proxy analyses provides new information on the environmental response of a rather large pre-Alpine lake system to rapid Lateglacial climatic fluctuations.

Major warmings at the onset of the Lateglacial and Holocene reveal differential environmental responses, largely controlled by the ecological and climatic preconditions. While lake productivity responded immediately to the warming at $14600 \mathrm{cal}$. a BP, the spread of woodlands in the surroundings and the decrease of detrital flux lagged the temperature increase by 500-750 a. Causes for the delay were persistent permafrost, plant-specific migrational lags and slow catchment stabilisation. In contrast, immediate ecosystem recovery within ca. 100 a in response to the Holocene temperature rise was favoured by already established forest cover and stable soils.

Shifts in local vegetation and temperature at the onset of the Younger Dryas occurred broadly synchronously. Although subtle sedimentological changes occurred at about the same time, the pronounced reduction of calcite precipitation, the general increase of detrital flux and the deposition of distinct detrital layers lagged the onset of the cooling by 150-300 a. This complex sedimentological response reflects the inertia of a large lake system, but probably also seasonal effects.

Sedimentological responses to short-term Lateglacial coolings are complex and largely determined by the environmental preconditions. As sedimentological changes during cold intervals are commonly characterised by variations in detrital flux, they are better recognisable during intervals of mainly autochthonous sedimentation (Mo-LG2, Mo-LG3), but hardly detectable for intervals with predominantly detrital sedimentation (Mo-LG1). The absence of a clear vegetational response to the low-amplitude Lateglacial coolings indicates a low climate sensitivity of local Pinus woodlands once a stable forest cover was established.

\section{Acknowledgements}

This study, carried out within the frame of the European Science Foundation EUROCORES Programme EuroCLIMATE (contract No. ERAS-CT-2003-980409 of the European Commission, DG Research, FP6, ESF project DecLakes no. 04-ECLIM-FP29), has been made possible thanks to the support and funding from the national agencies FWF (Austria, project no. I35-B06), DFG (Germany, project no. BR2208/2-2, AN554/1-2) and CNRS (France). We thank Jean-Louis Reyss (LSCE, Gif-sur-Yvette) for ${ }^{137} \mathrm{Cs}$ dating, Rudolf Naumann (GFZ, Potsdam) for providing XRD measurements, Juliane Herwig (GFZ, Potsdam) for assistance with the scanning electron microscope, Manuela Dziggel (GFZ, Potsdam) for help with some figures, Georg Schettler (GFZ, Potsdam) for help with carbon 
geochemistry analyses, Gertraud Roidmayr (Institute for Limnology, Mondsee) for picking ostracods and Richard Niederreiter (UWITEC, Mondsee) and Johann Knoll (Institute for Limnology, Mondsee) for assistance during the coring campaign. The laboratory staff at the contributing institutes are acknowledged for preparing numerous samples and running measurements smoothly. Furthermore, we are indebted to the Institute for Water Ecology, Fisheries and Lake Research in Scharfling, particularly Albert Jagsch, for providing logistical support in organising the field lab. We acknowledge the valuable comments of Roland Schmidt (Institute for Limnology, Mondsee), Michel Magny (Université Franche-Comté, Besançon) and an anonymous reviewer on an earlier version of the manuscript. The data presented in the figures here are available at doi: 10.1594/GFZ.SDDB.1420 and via the PANGAEA network.

\section{References}

- Ammann B. 1989. Periods of rapid environmental change around 12500 and 10000 years B.P., as recorded in Swiss lake deposits. Journal of Paleolimnology 1: 269-277.

- Ammann B, Lotter AF. 1989. Late-Glacial radiocarbon- and palynostratigraphy on the Swiss Plateau. Boreas 18: 109-126.

- Ammann B, Birks HJB, Drescher-Schneider R, Juggins S, Lang G, Lotter AF. 1993. Patterns of variation in late-glacial pollen stratigraphy along a northwest-southeast transect through Switzerland: a numerical analysis. Quaternary Science Reviews 12: 277-286.

- Ammann B, Lotter AF, Eicher U, Gaillard M-J, Wohlfarth B, Haeberli W, Lister G, Maisch M, Niessen F, Schlüchter C. 1994. The Würmian Late-glacial in lowland Switzerland. Journal of Quaternary Science 9: 119-125.

- Ammann B, Birks HJB, Brooks SJ, Eicher U, von Grafenstein U, Hofmann W, Lemdahl G, Schwander J, Tobolski K, Wick L. 2000. Quantification of biotic responses to rapid climatic changes around the Younger Dryas: a synthesis. Palaeogeography, Palaeoclimatology, Palaeoecology 159: 313-347.

- Behbehani AR, Handl M, Horsthemke E, Schmidt R, Schneider J. 1985. Possible lake level fluctuations within the Mondsee and Attersee. In Contributions to the Paleolimnology of the Trumer Lakes (Salzburg) and the Lakes Mondsee, Attersee and Traunsee (Upper Austria), DanielopolDL, SchmidtR, SchultzeE (eds). Limnologisches Institut der Österreichischen Akademie der Wissenschaften: Mondsee; 136-148.

- Beiwl C. 2008. Atlas der natürlichen Seen Österreichs mit einer Fläche $\geq 50$ ha. Morphometrie - Typisierung - Trophie. Bundesamt für Wasserwirtschaft: Vienna. 
- Berglund BE, Ralska-Jasiewiczowa M. 1986. Pollen analysis. In Handbook of Holocene Palaeoecology and Palaeohydrology, BerglundBE (ed.) Wiley: Chichester; 455-484.

- Birks HH, Ammann B. 2000. Two terrestrial records of rapid climatic change during the glacial-Holocene transition (14,000-9,000 calendar years B.P.) from Europe. Proceedings of the National Academy of Sciences USA 97: 1390-1394.

- Björck S, Walker MJC, Cwynar LC, Johnsen J, Knudsen K-L, Lowe JJ, Wohlfarth B. INTIMATE members. 1998. An event stratigraphy for the Last Termination in the North Atlantic region based on the Greenland ice-core record: a proposal by the INTIMATE group. Journal of Quaternary Science 13: 283-292.

- Brauer A, Casanova J. 2001. Chronology and depositional processes of the laminated sediment record from Lac d'Annecy, French Alps. Journal of Paleolimnology 25: $163-$ 177.

- Brauer A, Endres C, Günter C, Litt T, Stebich M, Negendank JFW. 1999a. High resolution sediment and vegetation responses to Younger Dryas climate change in varved lake sediments from Meerfelder Maar, Germany. Quaternary Science Reviews 18: $321-329$.

- Brauer A, Endres C, Negendank JFW. 1999b. Lateglacial calendar year chronology based on annually laminated sediments from Lake Meerfelder Maar, Germany. Quaternary International 61: 17-25.

- Brauer A, Günter C, Johnsen SJ, Negendank JFW. 2000. Land-ice teleconnections of cold climate periods during the last Glacial/Interglacial transition. Climate Dynamics 16: 229-239.

- Brauer A, Haug GH, Dulski P, Sigman DM, Negendank JFW. 2008a. An abrupt wind shift in western Europe at the onset of the Younger Dryas cold period. Nature Geoscience 1: 520-523.

- Brauer A, Mangili C, Moscariello A, Witt A. 2008b. Palaeoclimatic implications from micro-facies data of a 5900 varve time series from the Piànico interglacial sediment record, southern Alps. Palaeogeography, Palaeoclimatology, Palaeoecology 259: 121-135.

- Brauer A, Dulski P, Mangili C, Mingram J, Liu J. 2009. The potential of varves in high-resolution paleolimnological studies. PAGES News 17: 96-98.

- Brunskill GJ. 1969. Fayetteville Green Lake, New York. II. Precipitation and sedimentation of calcite in a meromictic lake with laminated sediments. Limnology and Oceanography 14: 830-847. 
- Danielopol DL, Geiger W, Tölderer-Farmer M, Orellana CP, Terrat MN. 1985. The ostracoda of Mondsee: spatial and temporal changes during the last fifty years. In Contributions to the Paleolimnology of the Trumer Lakes (Salzburg) and the Lakes Mondsee, Attersee and Traunsee (Upper Austria), DanielopolDL, SchmidtR, SchultzeE (eds). Limnologisches Institut der Österreichischen Akademie der Wissenschaften: Mondsee; 99-119.

- Draxler I. 1977. Pollenanalytische Untersuchungen von Mooren zur spät- und postglazialen Vegetationsgeschichte im Einzugsgebiet der Traun. Jahrbuch der Geologischen Bundesanstalt Wien 120: 131-163.

- Draxler I, van Husen D. 1987. Zur Vegetationsgeschichte und Stratigraphie des Würmspätglazials des Traungletschergebietes. Mitteilungen der Kommission für Quartärforschung der Österreichischen Akademie der Wissenschaften 7: 37-49.

- Drescher-Schneider R, Papesch W. 1998. A contribution towards the reconstruction of Eemian vegetation and climate in central Europe: first results of pollen and oxygenisotope investigations from Mondsee, Austria. Vegetation History and Archaeobotany 7: $235-240$.

- Eicher U. 1987. Die spätglazialen sowie die frühpostglazialen Klimaverhältnisse im Bereiche der Alpen: Sauerstoffisotopenkurven kalkhaltiger Sedimente. Geographica Helvetica 1987/2: 99-104.

- Eicher U, Siegenthaler U. 1976. Palynological and oxygen isotope investigations on Late-Glacial sediment cores from Swiss lakes. Boreas 5: 109-117.

- Eicher U, Siegenthaler U, Wegmüller S. 1981. Pollen and oxygen isotope analyses on late-and post-glacial sediments of the Tourbière de Chirens (Dauphiné, France). Quaternary Research 15: 160-170.

- Finsinger W, Belis C, Blockley SPE, Eicher U, Leuenberger M, Lotter AF, Ammann B. 2008. Temporal patterns in lacustrine stable isotopes as evidence for climate change during the late glacial in the Southern European Alps. Journal of Paleolimnology 40: 885-895.

- Friedrich M, Kromer B, Spurk M, Hofmann J, Kaiser KF. 1999. Paleo-environment and radiocarbon calibration as derived from Lateglacial/Early Holocene tree-ring chronologies. Quaternary International 61: 27-39.

- Gaillard M-J. 1985. Late-glacial and Holocene environments of some ancient lakes in the western Swiss Plateau. Dissertationes Botanicae 87: 273-336.

- Goslar T, Kuc T, Ralska-Jasiewiczowa M, Różański K, Arnold M, Bard E, van Geel B, Pazdur MF, Szeroczyńska K, Wicik B, Więckowski K, Walanus A. 1993. High- 
resolution lacustrine record of the Late Glacial/Holocene transition in Central Europe. Quaternary Science Reviews 12: 287-294.

- Grimm EC. 1987. CONISS: a FORTRAN 77 program for stratigraphically constrained cluster analysis by the method of incremental sum of squares. Computers and Geosciences 13: 13-35.

- Grimm EC. 1992. TILIA and TILIA GRAPH: pollen spreadsheet and graphics programs. In 8th International Palynological Congress, Aix-en-Provence, Program and Abstracts, 6-12 September 1992; 56.

- Haflidason H, Sejrup HP, Kristensen DK, Johnsen SJ. 1995. Coupled response of the late glacial climatic shifts of northwest Europe reflected in Greenland ice cores: evidence from the northern North Sea. Geology 23: 1059-1062.

- Hammarlund D, Aravena R, Barnekow L, Buchardt B, Possnert G. 1997. Multicomponent carbon isotope evidence of early Holocene environmental change and carbon-flow pathways from a hard-water lake in northern Sweden. Journal of Paleolimnology 18: 219-233.

- Heiri O, Millet L. 2005. Reconstruction of Late Glacial summer temperatures from chironomid assemblages in Lac Lautrey (Jura, France). Journal of Quaternary Science 20: 33-44.

- Herrmann M. 1990. Oberflächenkartierung der Mooswinkelbucht/Mondsee und Untersuchungen zur Tiefenstruktur. Diploma thesis, Georg-August-Universität, Göttingen.

- Hoek WZ. 2001. Vegetation response to the $\sim 14.7$ and $\sim 11.5$ ka cal. BP climate transitions: is vegetation lagging climate? Global and Planetary Change 30: 103-115.

- Horsthemke E. 1986. Sedimentgeologische Untersuchungen zum Problem von Seespiegelschwankungen im Bereich der neolithischen Siedlung der Station See im Mondsee (Salzkammergut, Österreich). Diploma thesis, Georg-August-Universität Göttingen.

- Hughen KA, Southon JR, Lehman SJ, Overpeck JT. 2000. Synchronous radiocarbon and climate shifts during the last deglaciation. Science 290: 1951-1954 .

- Irlweck K, Danielopol DL. 1985. Caesium-137 and lead-210 dating of recent sediments from Mondsee (Austria). Hydrobiologia 128: 175-185.

- Isarin RFB, Renssen H, Vandenberghe J. 1998. The impact of the North Atlantic Ocean on the Younger Dryas climate in northwestern and Central Europe. Journal of Quaternary Science 13: 447-453. 
- Jagsch A, Megay K. 1982. Mondsee. In Seenreinhaltung in Österreich, Vol. 6, WurzerE (ed.), Bundesministerium für Land- und Forstwirtschaft: Vienna; 155-163.

- Johnsen SJ, Clausen HB, Dansgaard W, Fuhrer K, Gundestrup N, Hammer CU, Iversen P, Jouzel J, Stauffer B, Steffensen JP. 1992. Irregular glacial interstadials recorded in a new Greenland ice core. Nature 359: 311-313.

- Jones RT, Marshall JD, Crowley SF, Bedford A, Richardson N, Bloemendal J, Oldfield F. 2002. A high resolution, multiproxy Late-glacial record of climate change and intrasystem responses in Northwest England. Journal of Quaternary Science 17: 329340.

- Kelts K, Hsü KJ. 1978. Freshwater carbonate sedimentation. In Lakes: Chemistry, Geology, Physics, Lerman A (ed.). Springer: New York; 295-324.

- Klasen N, Fiebig M, Preusser F, Reitner JM, Radtke U. 2007. Luminescence dating of proglacial sediments from the Eastern Alps. Quaternary International 164-165: 2132 .

- Klaus W. 1975. Das Mondsee-Interglazial, ein neuer Florenfundpunkt der Ostalpen. Jahrbuch des oberösterreichischen Musealvereines 120a: 315-344.

- $\quad$ Klee R, Schmidt R. 1987. Eutrophication of Mondsee (Upper Austria) as indicated by the diatom stratigraphy of a sediment core. Diatom Research 2: 55-76.

- Kohl H. 1998. Das Eiszeitalter in Oberösterreich Teil II: Die eiszeitliche Vergletscherung in Oberösterreich. Jahrbuch des oberösterreichischen Musealvereines 143a: 175-390.

- Litt T, Stebich M. 1999. Bio- and chronostratigraphy of the lateglacial in the Eifel region, Germany. Quaternary International 61: 5-16.

- Litt T, Brauer A, Goslar T, Merkt J, Bałaga K, Müller H, Ralska-Jasiewiczowa M, Stebich M, Negendank JFW. 2001. Correlation and synchronisation of Lateglacial continental sequences in northern central Europe based on annually laminated lacustrine sediments. Quaternary Science Reviews 20: 1233-1249.

- Löffler H. 1983. Aspects of the history and evolution of Alpine lakes in Austria. Hydrobiologia 100: 143-152.

- Loizeau J-L, Span D, Coppee V, Dominik J. 2001. Evolution of the trophic state of Lake Annecy (eastern France) since the last glaciation as indicated by iron, manganese and phosphorus speciation. Journal of Paleolimnology 25: 205-214.

- Lotter AF. 1989. Evidence of annual layering in Holocene sediments of Soppensee, Switzerland. Aquatic Sciences 51: 19-31. 
- Lotter AF. 1999. Late-glacial and Holocene vegetation history and dynamics as shown by pollen and plant macrofossil analyses in annually laminated sediments from Soppensee, central Switzerland. Vegetation History and Archaeobotany 8: 165-184.

- Lotter AF, Eicher U, Siegenthaler U, Birks HJB. 1992. Late-glacial climatic oscillations as recorded in Swiss lake sediments. Journal of Quaternary Science 7: 187-204.

- Lotter A, Sturm M, Teranes J, Wehrli B. 1997. Varve formation since 1885 and highresolution varve analyses in hypertrophic Baldeggersee (Switzerland). Aquatic Sciences 59: 304-325.

- Lotter AF, Birks HJB, Eicher U, Hofmann W, Schwander J, Wick L. 2000. Younger Dryas and Allerød summer temperatures at Gerzensee (Switzerland) inferred from fossil pollen and cladoceran assemblages. Palaeogeography, Palaeoclimatology, Palaeoecology 159: 349-361.

- Lücke A, Brauer A. 2004. Biogeochemical and micro-facial fingerprints of ecosystem response to rapid Late Glacial climatic changes in varved sediments of Meerfelder Maar (Germany). Palaeogeography, Palaeoclimatology, Palaeoecology 211: 139155.

- Magny M, Aalbersberg G, Bégeot C, Benoit-Ruffaldi P, Bossuet G, Disnar J-R, Heiri $O$, Laggoun-Defarge F, Mazier F, Millet L, Peyron O, Vannière B, Walter-Simonnet A$V$. 2006. Environmental and climatic changes in the Jura mountains (eastern France) during the Lateglacial-Holocene transition: a multi-proxy record from Lake Lautrey. Quaternary Science Reviews 25: 414-445.

- Marshall JD, Jones RT, Crowley SF, Oldfield F, Nash S, Bedford A. 2002. A high resolution Late-Glacial isotopic record from Hawes Water, Northwest England. Climatic oscillations: calibration and comparison of palaeotemperature proxies. Palaeogeography, Palaeoclimatology, Palaeoecology 185: 25-40.

- Merkt J, Müller H. 1999. Varve chronology and palynology of the Lateglacial in Northwest Germany from lacustrine sediments of Hämelsee in Lower Saxony. Quaternary International 61: 41-59.

- Moscariello A, Schneider AM, Filippi ML. 1998. Late glacial and early Holocene palaeoenvironmental changes in Geneva Bay (Lake Geneva, Switzerland). Palaeogeography, Palaeoclimatology, Palaeoecology 140: 51-73.

- Muscheler R, Kromer B, Björck S, Svensson A, Friedrich M, Kaiser KF, Southon J. 2008. Tree rings and ice cores reveal ${ }^{14} \mathrm{C}$ calibration uncertainties during the Younger Dryas. Nature Geoscience 1: 263-267. 
- Nagl H. 1976. Geographische Untersuchungen. In Attersee. Vorläufige Ergebnisse des OECD-Seeneutrophierungs- und des MaB-Programms, Gmunden, Austria; 8-28.

- Namiotko T, Danielopol DL, Pichler M, von Grafenstein U. 2009. Occurrence of an Arctic ostracod species, Fabaeformiscandona harmsworthi (Scott, 1899) (Ostracoda, Candonidae) in late glacial sediments of Lake Mondsee (Austria). Crustaceana 82: 1209-1212.

- NGRIP members. 2004. High-resolution record of Northern Hemisphere climate extending into the last interglacial period. Nature 431: 147-151.

- Ohlendorf C, Sturm M. 2001. Precipitation and dissolution of calcite in a Swiss high alpine lake. Arctic, Antarctic, and Alpine Research 33: 410-417.

- Rasmussen SO, Andersen KK, Svensson AM, Steffensen JP, Vinther BM, Clausen HB, Siggaard-Andersen M-L, Johnsen SJ, Larsen LB, Dahl-Jensen D, Bigler M, Röthlisberger R, Fischer H, Goto-Azuma K, Hansson ME, Ruth U. 2006. A new Greenland ice core chronology for the last glacial termination. Journal of Geophysical Research 111: D06102.

- Reitner JM. 2007. Glacial dynamics at the beginning of Termination I in the Eastern Alps and their stratigraphic implications. Quaternary International 164-165: 64-85.

- Rundgren M, Ingólfsson Ó. 1999. Plant survival in Iceland during periods of glaciation? Journal of Biogeography 26: 387-396.

- Schmidt R. 1981. Grundzüge der spät- und postglazialen Vegetations- und Klimageschichte des Salzkammergutes (Österreich) aufgrund palynologischer Untersuchungen von See- und Moorprofilen. Mitteilungen der Kommission für Quartärforschung der Österreichischen Akademie der Wissenschaften 3: 1-96.

- Schmidt R, Wunsam S, Brosch U, Fott J, Lami A, Marchetto A, Löffler H, Müller HW, Pražáková M, Schwaighofer B. 1998. Late and post-glacial history of meromictic Längsee (Austria), in respect to climate change and anthropogenic impact. Aquatic Sciences 60: 56-88.

- $\quad$ Schmidt R, van den Bogaard C, Merkt J, Müller J. 2002. A new Lateglacial chronostratigraphic tephra marker for the south-eastern Alps: the Neapolitan Yellow Tuff (NYT) in Längsee (Austria) in the context of a regional biostratigraphy and palaeoclimate. Quaternary International 88: 45-56.

- Schultze E, Niederreiter R. 1990. Paläolimnologische Untersuchungen an einem Bohrkern aus dem Profundal des Mondsees (Oberösterreich). Linzer biologische Beiträge 22: 213-235. 
- Schwalb A. 2003. Lacustrine ostracodes as stable isotope recorders of late-glacial and Holocene environmental dynamics and climate. Journal of Paleolimnology 29: 265351.

- Schwander J, Eicher U, Ammann B. 2000. Oxygen isotopes of lake marl at Gerzensee and Leysin (Switzerland), covering the Younger Dryas and two minor oscillations, and their correlation to the GRIP ice core. Palaeogeography, Palaeoclimatology, Palaeoecology 159: 203-214.

- Stebich M, Mingram J, Han J, Liu J. 2009. Late Pleistocene spread of (cool-)temperate forests in Northeast China and climate changes synchronous with the North Atlantic region. Global and Planetary Change 65: 56-70.

- Stockmarr J. 1971. Tablets with spores used in absolute pollen analysis. Pollen et Spores 13: 615-621.

- Stuiver M, Grootes PM, Braziunas TF. 1995. The GISP $\delta^{18} O$ climate record of the past 16,500 years and the role of the sun, ocean and volcanoes. Quaternary Research 44: $341-354$.

- Sturm M, Matter A. 1978. Turbidites and varves in Lake Brienz (Switzerland): deposition of clastic detritus by density currents. In Modern and Ancient Lake Sediments, MatterA, TuckerME (eds). Special Publication of the International Association of Sedimentologists 2. Blackwell: Oxford; 147-168.

- Swierczynski T, Lauterbach S, Dulski P, Brauer A. 2009. Die Sedimentablagerungen des Mondsees (Oberösterreich) als ein Archiv extremer Abflussereignisse der letzten 100 Jahre. In Klimawandel in Österreich - Die letzten 20.000 Jahre ... und ein Blick voraus, SchmidtR, MatullaC, PsennerR (eds). Innsbruck University Press: Innsbruck; $115-126$.

- van Husen D. 1977. Zur Fazies und Stratigraphie der jungpleistozänen Ablagerungen im Trauntal. Jahrbuch der Geologischen Bundesanstalt Wien 120: 1-130.

- van Husen D. 1979. Verbreitung, Ursachen und Füllung glazial übertiefter Talabschnitte an Beispielen aus den Ostalpen. Eiszeitalter und Gegenwart 29: 9-22.

- van Husen D. 1989. Blatt 65 - Mondsee. Geologische Karte der Republik Österreich 1:50 000. Geologische Bundesanstalt, Wien.

- van Husen D. 1997. LGM and late-glacial fluctuations in the Eastern Alps. Quaternary International 38-39: 109-118.

- van Husen D. 2004. Quaternary glaciations in Austria. In Quaternary Glaciations: Extent and Chronology, Part 1: Europe, EhlersJ, GibbardPL (eds). Elsevier: Amsterdam; 1-13. 
- von Grafenstein U, Erlenkeuser H, Müller J, Trimborn P, Alefs J. 1996. A 200 year mid-European air temperature record preserved in lake sediments: An extension of the $\delta O_{P}$-air temperature relation into the past. Geochimica et Cosmochimica Acta 60: $4025-4036$.

- von Grafenstein U, Erlenkeuser H, Brauer A, Jouzel J, Johnsen SJ. 1999a. A midEuropean decadal isotope-climate record from 15,500 to 5000 years B.P. Science 284 : 1654-1657.

- von Grafenstein U, Erlenkeuser H, Trimborn P. 1999b. Oxygen and carbon isotopes in modern fresh-water ostracod valves: assessing vital offsets and autecological effects of interest for palaeoclimate studies. Palaeogeography, Palaeoclimatology, Palaeoecology 148: 133-152.

- Walker MJC. 1995. Climatic changes in Europe during the last glacial/interglacial transition. Quaternary International 28: 63-76.

- Wick L. 2000. Vegetational response to climatic changes recorded in Swiss Late Glacial lake sediments. Palaeogeography, Palaeoclimatology, Palaeoecology 159: 231-250.

- Wohlfarth B, Gaillard M-J, Haeberli W, Kelts K. 1994. Environment and climate in southwestern Switzerland during the last termination 15-10 ka BP. Quaternary Science Reviews 13: 361-394.

- $\quad$ Y Z Z. 2007. Rapid response of forested vegetation to multiple climatic oscillations during the last deglaciation in the northeastern United States. Quaternary Research 67: 297-303.

- Zarzycki K, Trzcińska-Tacik H, Różański W, Szelag Z, Wołek J, Korzeniak U. 2002. Ecological Indicator Values of Vascular Plants of Poland. W Szafer Institute of Botany, Polish Academy of Sciences: Kraków. 


\section{$\mathrm{F}$}
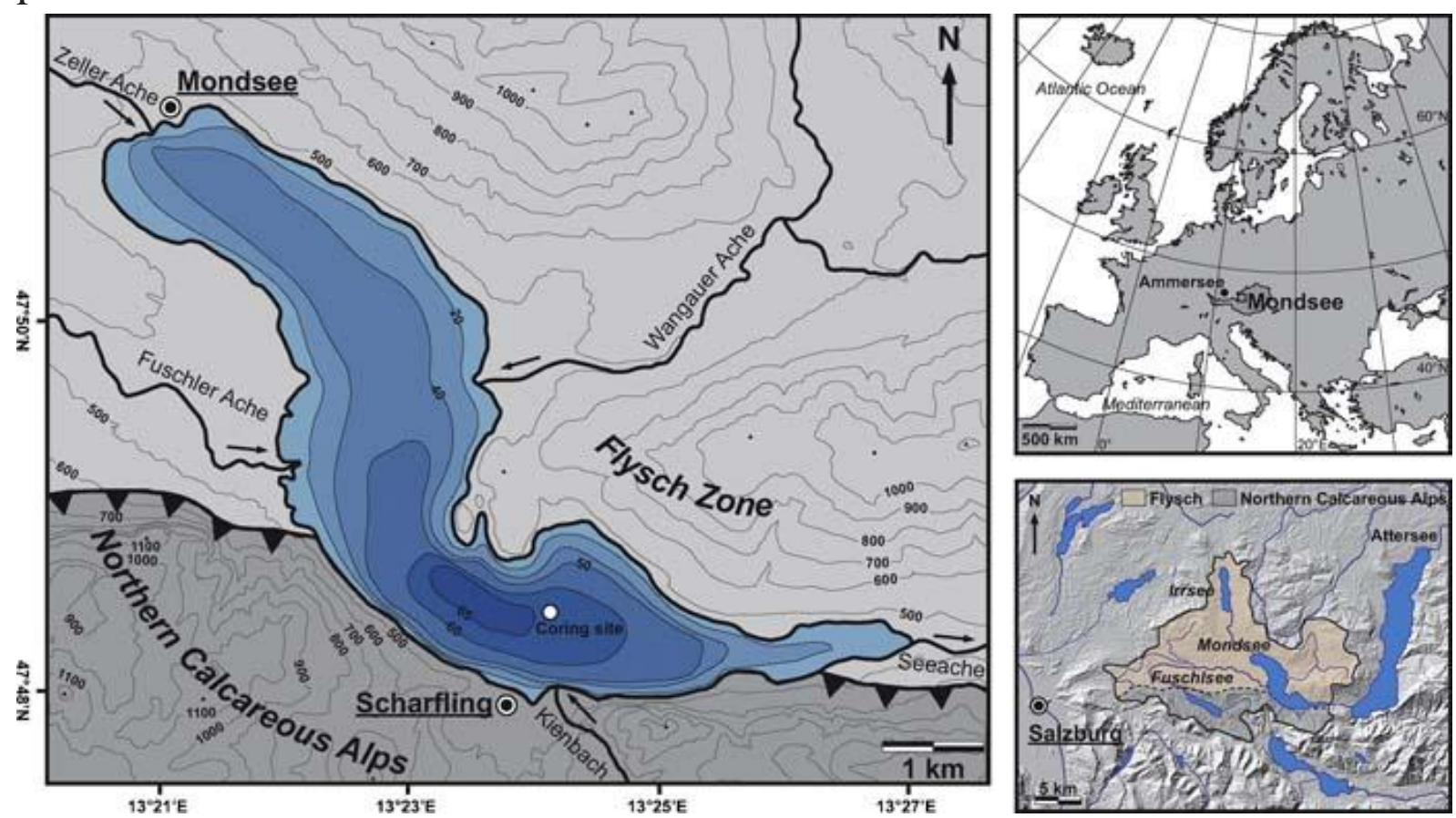

Figure 1. Bathymetry of Lake Mondsee and simplified geological maps of the entire catchment and the surrounding area (modified after Nagl, 1976, and van Husen, 1989). Isobaths are given with corresponding depths in metres below lake level. The small river Kienbach, which drains the Northern Calcareous Alps, is the main source of allochthonous detrital material to the coring site. 


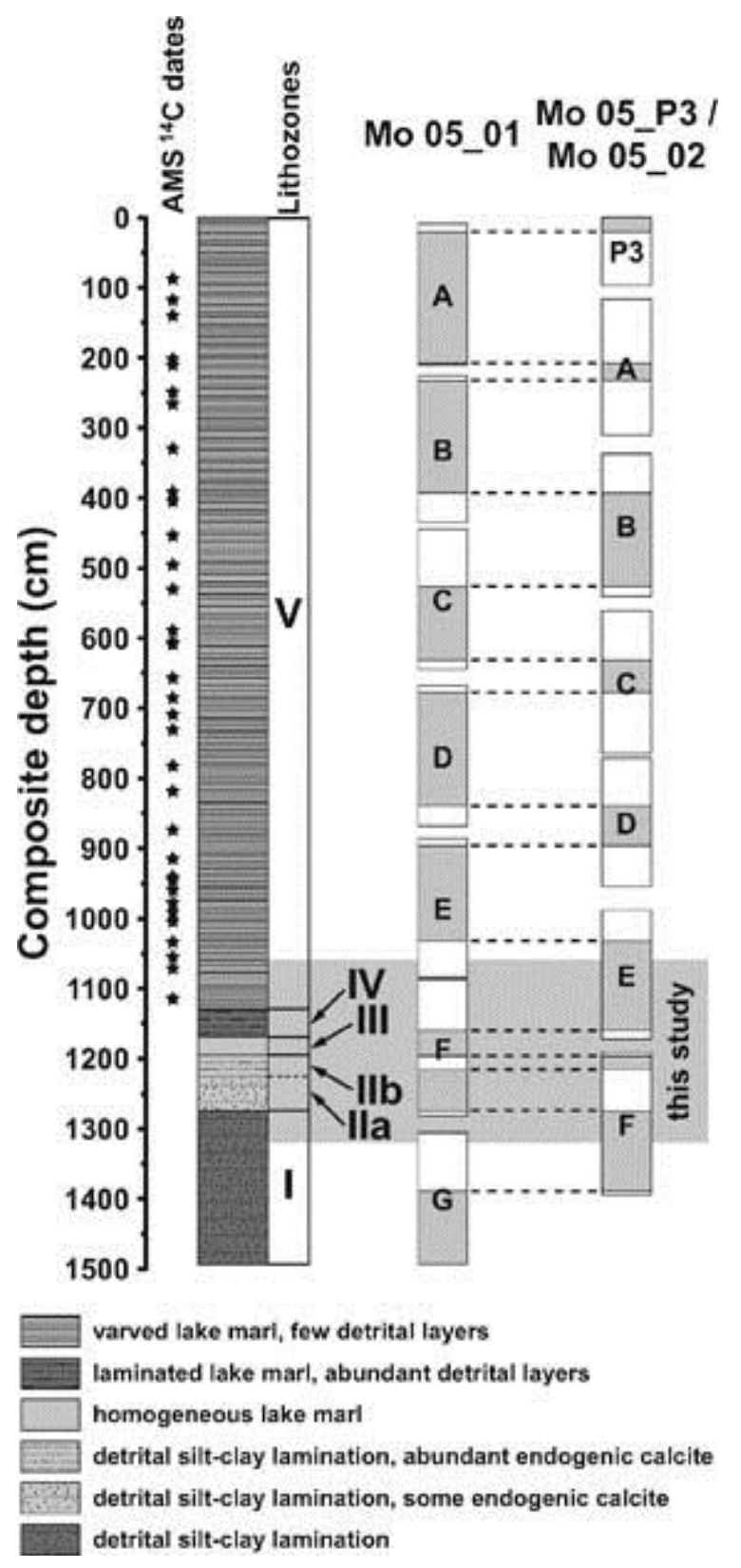

Figure 2. Correlation between the segments of cores Mo 05_01 and Mo 05_02 (grey shaded intervals indicate sections included in the composite profile), schematic lithological profile and corresponding lithozones of the Lake Mondsee sediment record. Positions of radiocarbondated samples within Lithozone V are indicated by stars. Further information on AMS radiocarbon dating is presented in the online supporting Appendix S1. The grey shading between 1060.0 and $1320.0 \mathrm{~cm}$ corresponds to the sequence investigated in detail in this study. 
A Lithozone I $(1489-1274 \mathrm{~cm})$

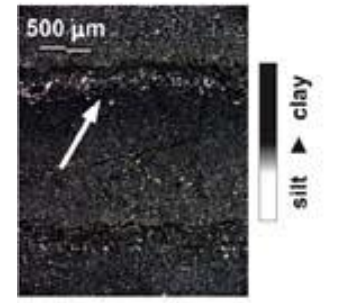

silty detritus within clay layer

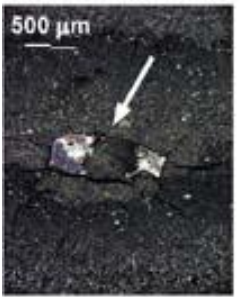

dropstone within silt layer

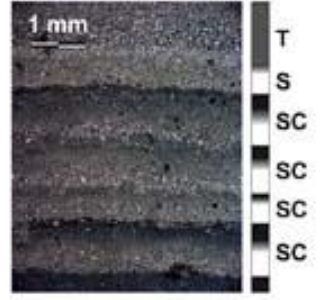

silt-clay laminae (SC) and turbidite (T)

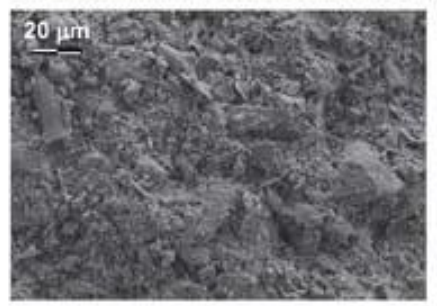

detrital carbonates (SEM)

\section{B Lithozone III (1195-1169 cm)}

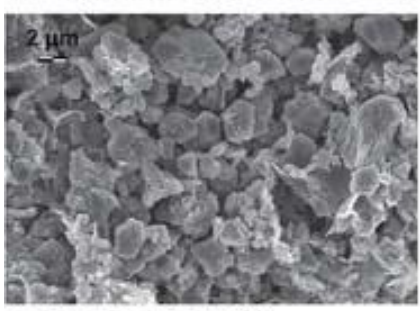

endogenic calcite (SEM)

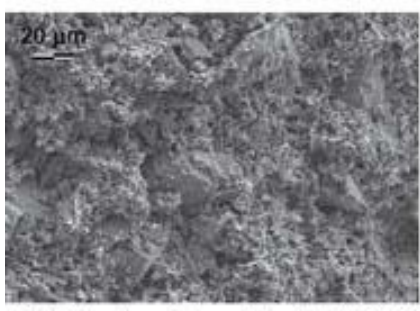

detrital carbonates within turbidite (SEM)

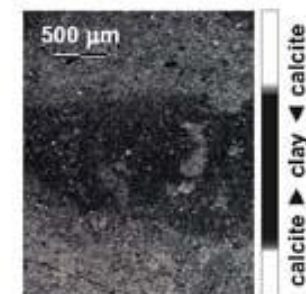

clay layer

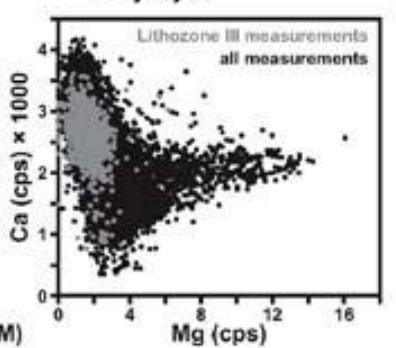

C Lithozone IV (1169-1129 cm)

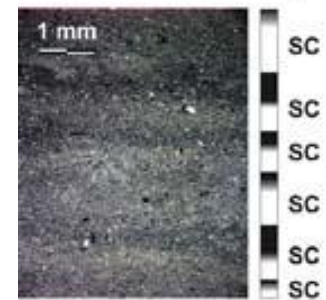

faint silt-clay (SC) lamination

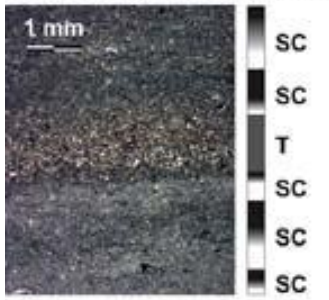

silt-clay laminae (SC) and turbidite (T)

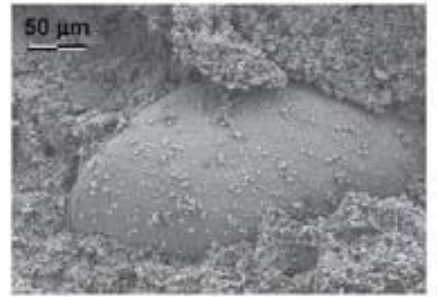

ostracod valve (SEM)

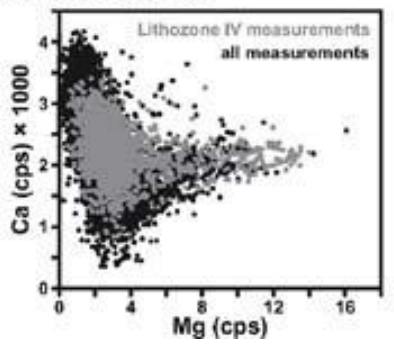

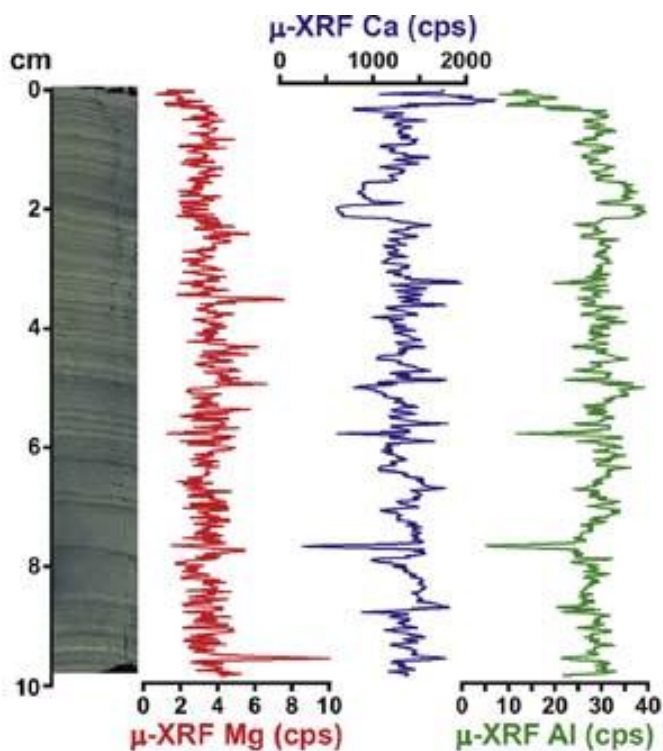

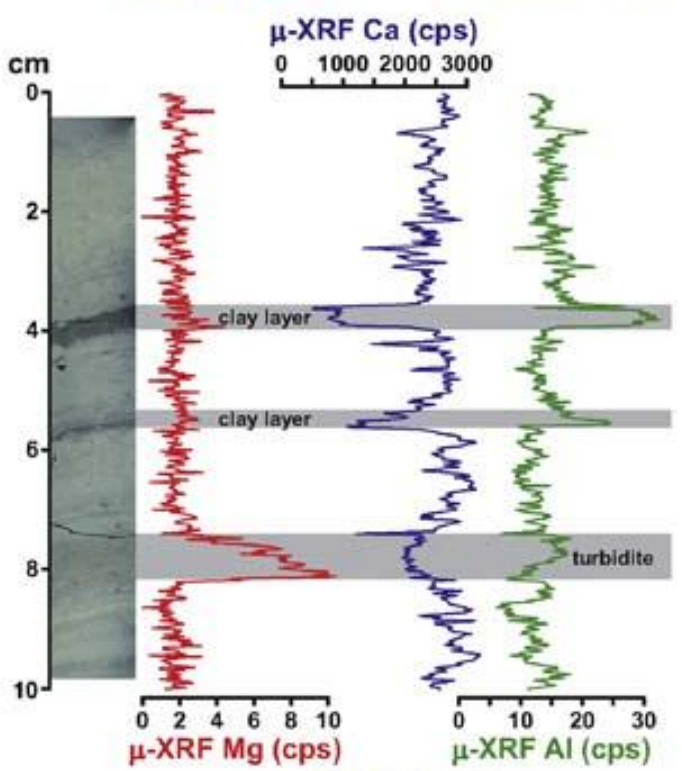

$\mu-X R F \mathrm{Ca}$ (cps)

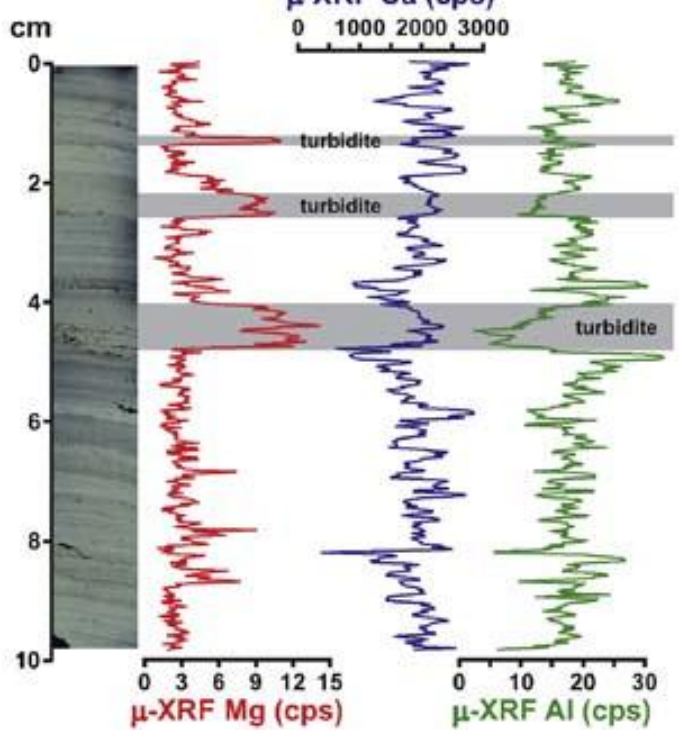

Figure 3. Typical sediment microfacies of different lithozones and results of $\mu$-XRF element scanning of representative sediment slabs. Scanned thin sections (cross-polarised light) along the $\mu$-XRF scans 
are displayed for comparison. Detail photographs were taken on thin sections under a Zeiss Axiophot polarisation microscope at 25-50x magnification with cross-polarised light and on dried sediment samples under a scanning electron microscope (SEM). For further explanations on the figures see the text. (A) Laminated sediments of Lithozone I. Silt-clay laminae (SC) are composed of a basal silt layer of detrital carbonates and siliciclastics which grades into a clay layer. Frequently intercalated turbidites $(T)$ represent deposition by underflows. Occasional silt-sized minerogenic detritus within the clayey sub-layer reflects a secondary pulse of detrital flux. Dropstones within the silty sub-layer originate from drift-ice transport. (B) Homogeneous lake marl of mainly microcrystalline endogenic calcite in Lithozone III. Two intercalated distinct clay layers (high Al and low Ca counts) and a turbidite composed of detrital carbonates (high $\mathrm{Mg}$ and intermediate $\mathrm{Ca}$ and $\mathrm{Al}$ counts) reflect occasional surface runoff events. The $\mu$-XRF cross-plot reveals the high abundance of endogenic calcite (Ca counts) and low amounts of dolomitic detritus (Mg counts). (C) Faintly laminated sediment of Lithozone IV. Distinct turbidites intercalated within the silt-clay laminae are reflected by high $\mathrm{Mg}$ counts, whereas $\mathrm{Ca}$ and $\mathrm{Al}$ counts remain on a low/intermediate level. The $\mu$-XRF cross-plot reflects the continuing presence of endogenic calcite (Ca counts) but also increased amounts of dolomitic detritus (Mg counts).

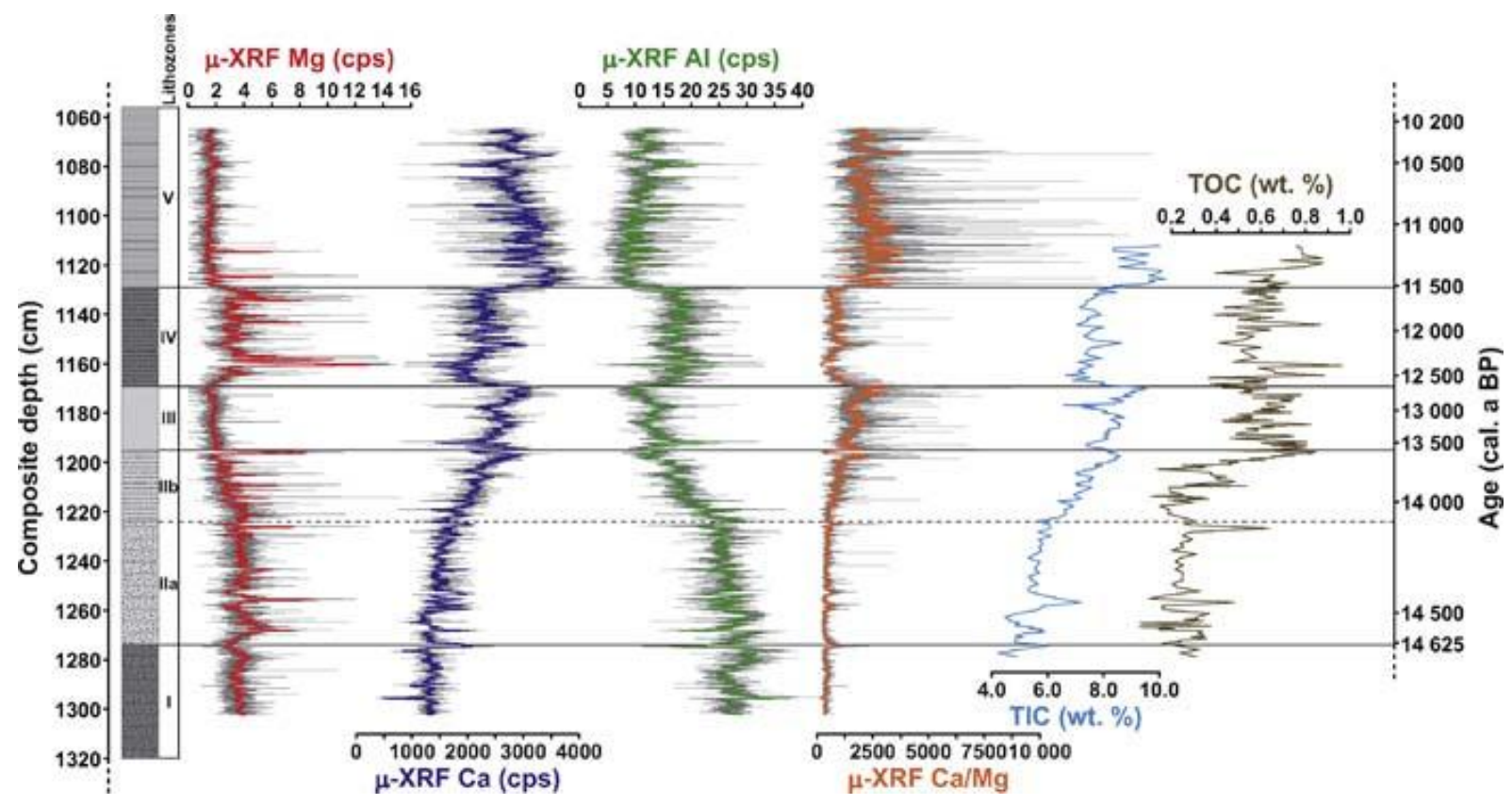

Figure 4. Results of $\mu$-XRF element scanning (thin lines: measurements at $200 \mu \mathrm{m}$ resolution; thick lines: 25-point running mean) and carbon geochemistry analyses obtained from the Lake Mondsee sediments across the Last Glacial-Holocene transition. $\mu$-XRF Mg counts reflect input of detrital dolomite and Al counts those of detrital siliciclastics, whereas Ca counts and TIC contents reflect variations in the abundance of endogenic calcite. 


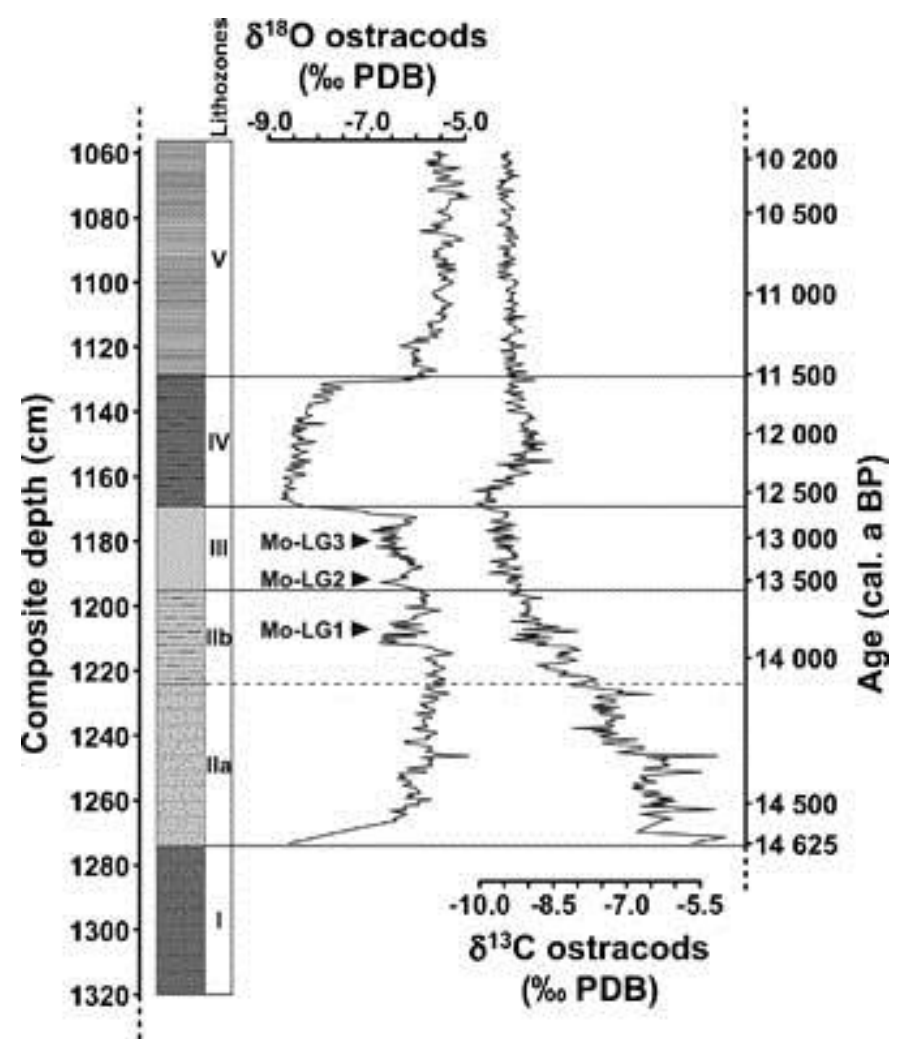

Figure 5. Results of stable isotope measurements on juvenile ostracod (Candona neglecta and Fabaeformiscandona harmsworthi) valves obtained from the Lake Mondsee sediments across the Last Glacial-Holocene transition. $\delta^{18} \mathrm{O}$ values, which are considered as a temperature proxy, are not corrected for the species-specific vital offset. 


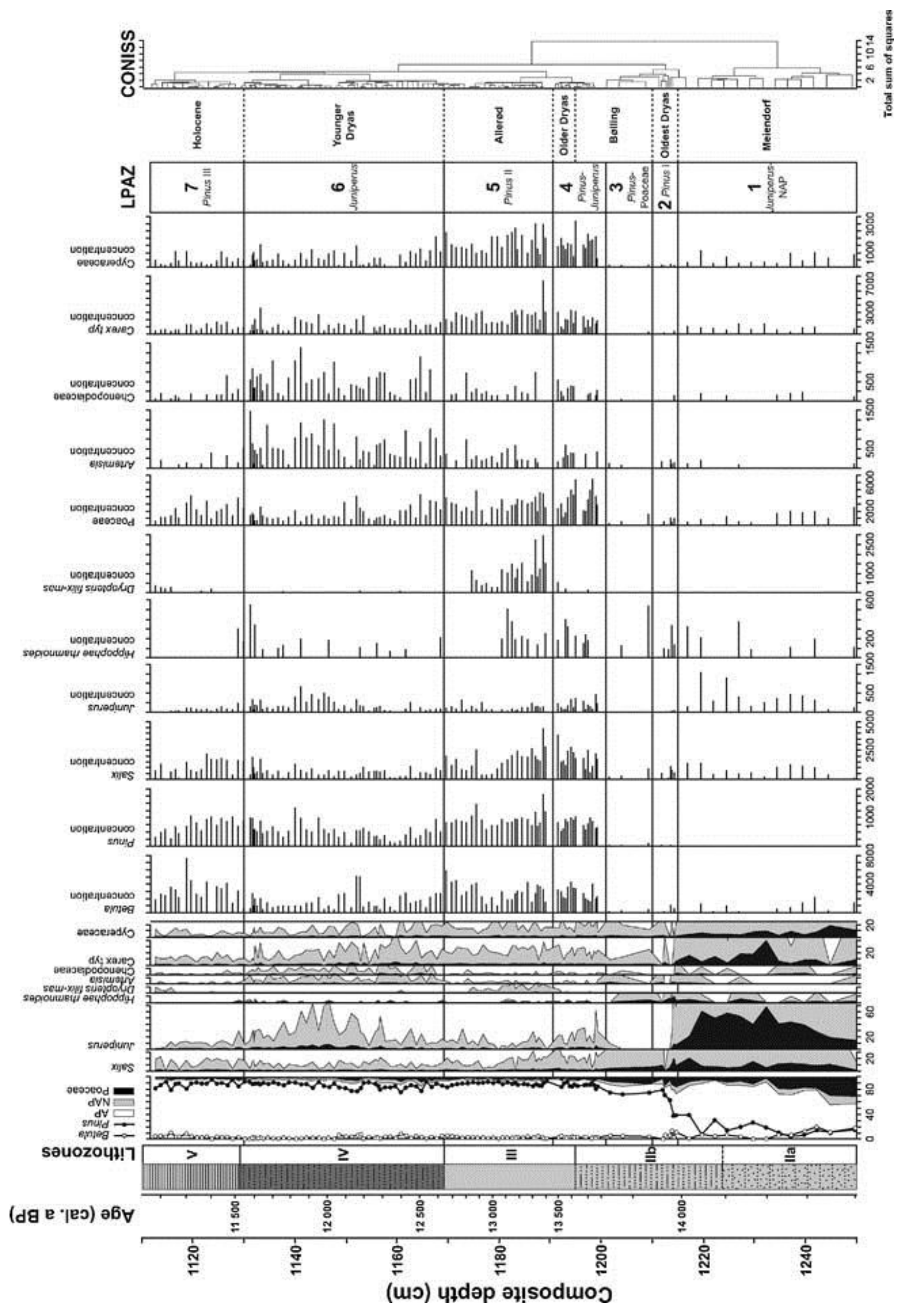


Figure 6. Pollen percentage/concentration diagram for Lake Mondsee for selected taxa. Outline curves in the percentage diagrams represent a 10x exaggeration. Pollen concentrations are given as pollen grains per $\mathrm{cm}^{3}$ dry sediment.

A
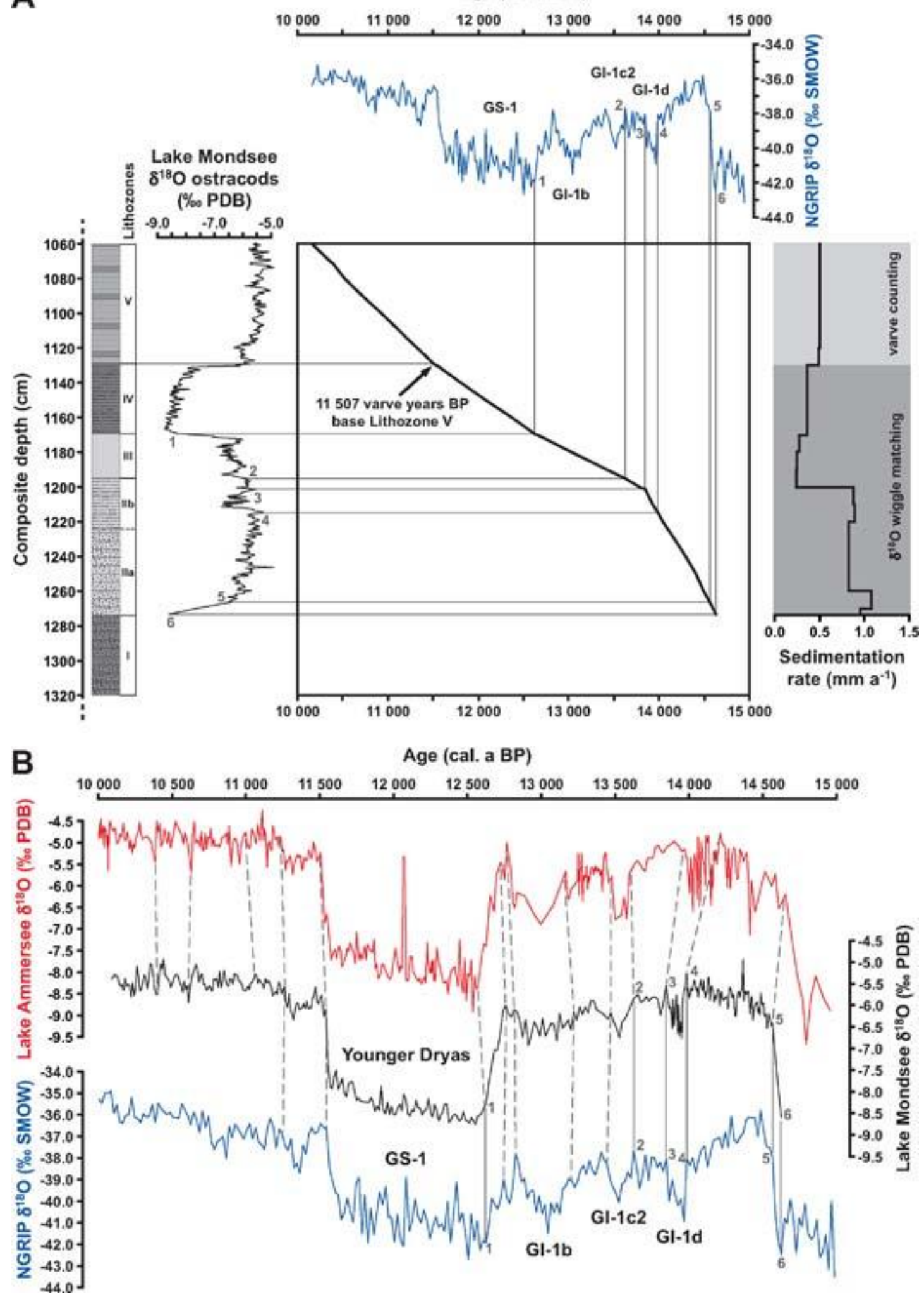

Figure 7. (A) Age-depth model for the Lateglacial part of the Lake Mondsee sediment record based on wiggle matching between the $\delta^{18} \mathrm{O}$ records from Lake Mondsee and NGRIP, the latter plotted 
according to the GICC05 chronology (Rasmussen et al., 2006), corrected by an offset of -65 a (Muscheler et al., 2008). For further information on the chronological tie points see the text and Table 1. (B) Comparison of the NGRIP, Lake Mondsee and Lake Ammersee (von Grafenstein et al., 1999a) $\delta^{18} \mathrm{O}$ records. Solid lines and arabic numerals in both figures indicate the six tie points used for the construction of the Lateglacial age model (Table 1). The varve counting-based age of 11 507 varve a BP for the base of Lithozone $V$ at $1129.0 \mathrm{~cm}$ in the Lake Mondsee record is used as an additional tie point for the Lateglacial age model. Additional dashed lines reveal the close agreement between the records. Slight differences between the Lake Mondsee and Lake Ammersee $\delta^{18} \mathrm{O}$ records prior to ca. $13500 \mathrm{cal}$. a BP might be an artefact of the different approaches used for establishing the chronologies

Table 1. Chronological tie points used for the establishment of the Lateglacial age-depth model of the Lake Mondsee sediment record. Isotopic marker points in the Lake Mondsee $\delta^{18} \mathrm{O}$ record are given with their depth in the composite profile and corresponding ages in the NGRIP record (Rasmussen et al., 2006). Sample ages between these tie points were interpolated linearly.

$\begin{array}{lccc}\begin{array}{l}\text { Marker } \\ \text { point }\end{array} & \text { Marker point description } & \text { Age } & \text { Lake Mondsee } \\ \text { (cal. a } & \text { composite depth } \\ & & \text { BP) } & (\mathrm{cm})\end{array}$

$*$

The Greenland GICC05 chronology (Rasmussen et al., 2006) was transferred from years b2k (before AD 2000) into cal. a BP (before present/AD 1950) and shifted by -65 a (Muscheler et al., 2008).

Base of Lithozone V in Lake

Mondsee, age determined by

11507

1129.00

varve chronology

1

End of GI-1/GS-1 transition in

Greenland

$12625^{*}$

1169.25

2

Onset of Greenland isotope

substage GI-1c2 


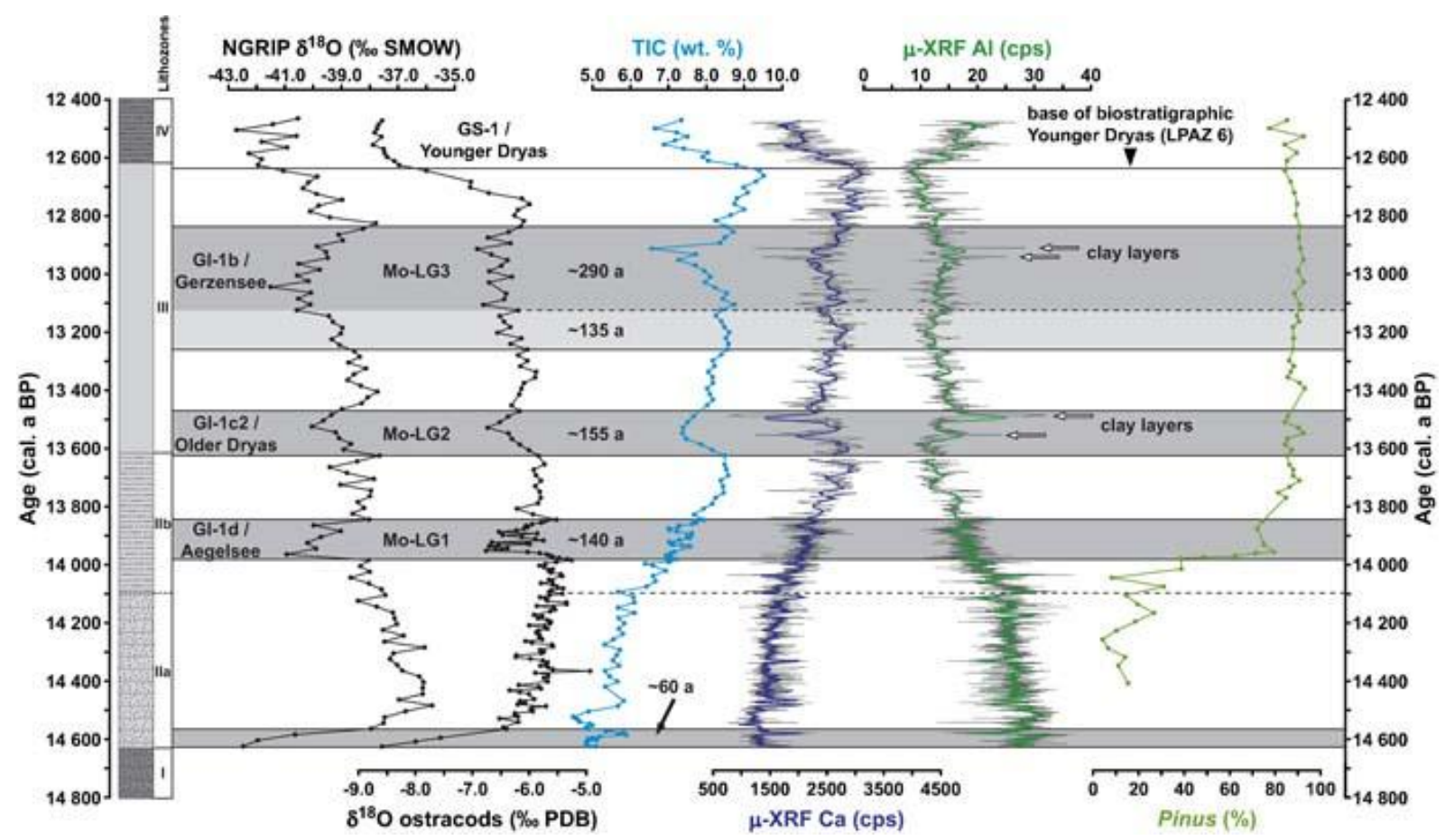

Figure 8. Detailed comparison of selected proxy data from the Lake Mondsee sediment record during the Lateglacial Interstadial. Grey shaded areas indicate periods of major proxy changes given with their approximate duration in years. Oxygen isotope ratios obtained from juvenile ostracod valves (not corrected for the species-specific vital offset) are considered as a temperature proxy. Thin lines in the results of $\mu$-XRF element scanning represent measurements at $200 \mu \mathrm{m}$ resolution. Thick lines indicate a 25-point running mean. Small-scale cold events seen in the oxygen isotope record (Mo-LG2 and Mo-LG3; for further explanations see the text) are reflected by reductions in TIC and Ca counts, both considered as a proxy for biochemically precipitated calcite. Al counts reflect the corresponding increase of siliciclastic detrital input and particularly the occurrence of clay layers during cooling events Mo-LG2 and Mo-LG3. The Pinus pollen record reveals that small-scale coolings had no/only minor influence on local forest vegetation. 


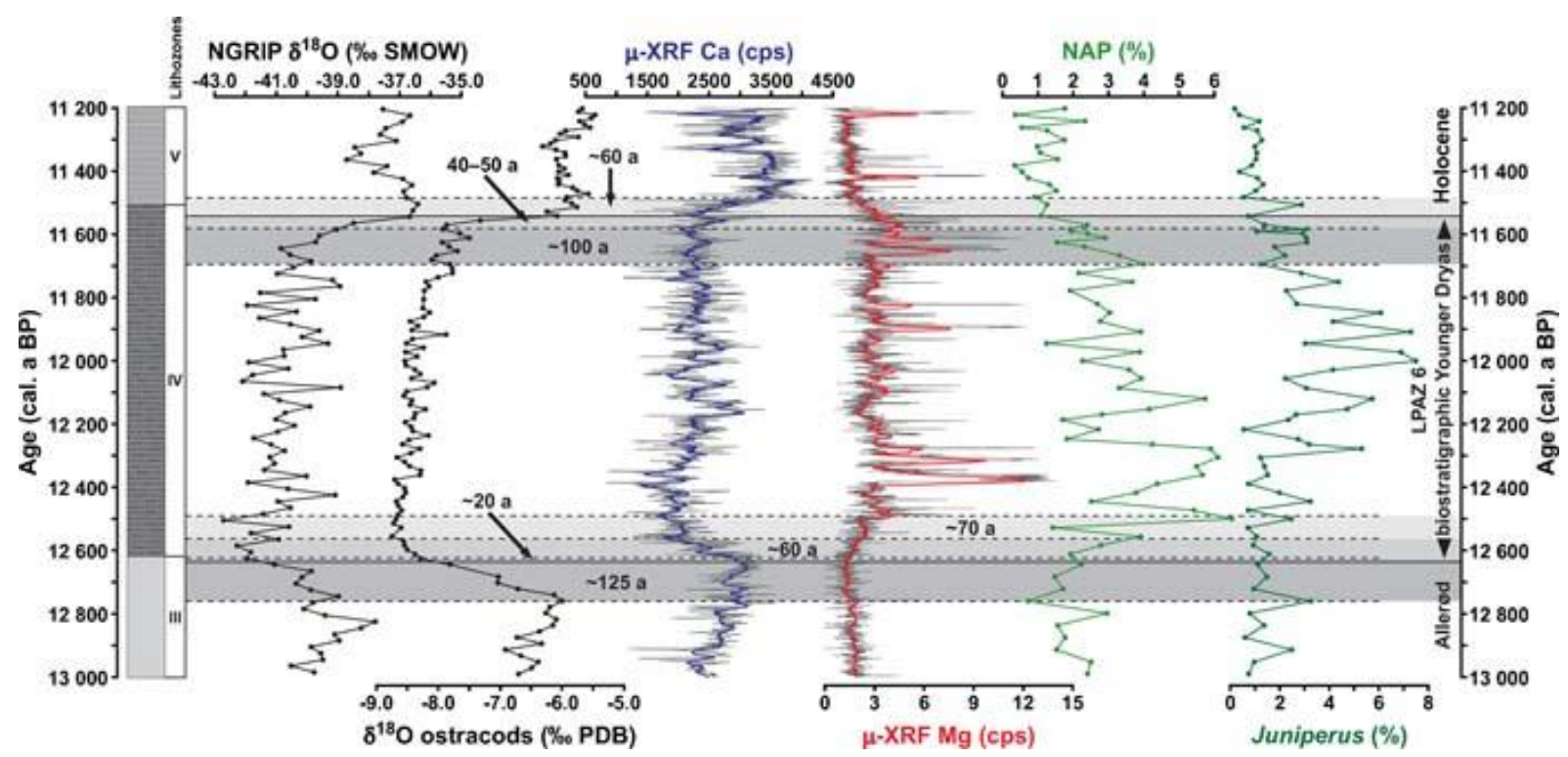

Figure 9. Detailed comparison of selected proxy data from the Lake Mondsee sediment record across the Allerød-Younger Dryas and Younger Dryas-Holocene transitions. Grey shaded areas indicate periods of major proxy changes with their approximate duration given in years. Oxygen isotope ratios obtained from juvenile ostracod valves are not corrected for the species-specific vital offset. Thin grey lines in the results of $\mu-X R F$ element scanning represent measurements at $200 \mu \mathrm{m}$ resolution. Thick coloured lines indicate a 25 -point running mean. $\mu$-XRF Ca counts are considered as a proxy for biochemically precipitated calcite, whereas $\mathrm{Mg}$ counts reflect detrital input (dolomite). Pollen records of NAP and Juniperus are plotted as representatives for shrub/herb vegetation. 